\title{
Data report: regional stratigraphic correlation and a revised composite depth scale for IODP Expedition $302^{1}$
}

\author{
Matt O'Regan, ${ }^{2}$ Tatsuhiko Sakamoto, ${ }^{3}$ and John King ${ }^{2}$
}

\section{Chapter contents}

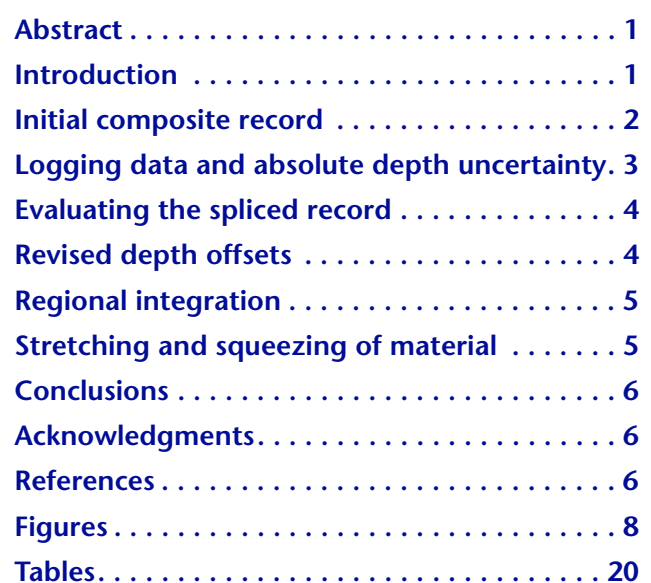

${ }^{1}$ O'Regan, M., Sakamoto, T., and King, J., 2008. Data report: regional stratigraphic correlation and a revised composite depth scale for IODP Expedition 302. In Backman, J., Moran, K., McInroy, D.B., Mayer, L.A., and the Expedition 302 Scientists, Proc. IODP, 302: Edinburgh (Integrated Ocean Drilling Program Management International, Inc.).

doi:10.2204/iodp.proc.302.202.2008

${ }^{2}$ Graduate School of Oceanography, University of Rhode Island, Narragansett RI 02882, USA. oregan@gso.uri.edu.

${ }^{3}$ Institute For Research on Earth Evolution (IFREE), Japan Agency for Marine Earth Science and Technology (JAMSTEC), 2-15 Natsushima-Cho, Yokosuka-city, Kanagawa 237-0061, Japan.

\section{Abstract}

Expedition 302 of the Integrated Ocean Drilling Program (IODP), also known as the Arctic Coring Expedition (ACEX), successfully penetrated a sequence of Cenozoic sediments draping the crest of the Lomonosov Ridge in the central Arctic Ocean. The cumulative sedimentary record spans the last $57 \mathrm{~m}$.y. and was recovered from three sites located within $15 \mathrm{~km}$ of each other. Merging the recovered cores onto a common depth scale that accurately reflects their stratigraphic placement below the seafloor is a fundamental step toward interpreting this unique sedimentary record. However, the lack of overlapping recovery in adjacent holes and intervals of high core disturbance complicated traditional methods of stratigraphic correlation. Here we present a revised composite depth scale for the ACEX sediments, generated in part by performing a regional stratigraphic correlation with sediments recovered from previous expeditions to the Lomonosov Ridge. The revised depth scale also reassesses the offsets for cores in the upper 55 meters below seafloor, where no overlapping recovery was acquired, and proposes modifications to these depths.

\section{Introduction}

During Integrated Ocean Drilling Program (IODP) Expedition 302, also known as the Arctic Coring Expedition (ACEX), four sites were drilled near $88^{\circ} \mathrm{N}$ on the crest of the Lomonosov Ridge in the central Arctic Ocean (Fig. F1). These sites were located along a single multichannel seismic reflection profile (AWI91090) acquired in 1991 (Fütterer, 1992), where a $450 \mathrm{~m}$ thick sequence of flat-lying Cenozoic sediments was predicted from seismic interpretations (Jokat et al., 1995). ACEX drilling penetrated $428 \mathrm{~m}$ into this sediment sequence, recovering $399 \mathrm{~m}$ of core (see the "Sites M0001-M0004" chapter). Although overlapping recovery was only achieved in the upper $\sim 30$ meters below seafloor (mbsf) (Fig. F2), the coherent seismostratigraphy imaged along Profile AWI-91090 allowed material recovered from four of the five sites to be confidently integrated into a composite profile and placed on a common depth scale.

Following conventions established during the Deep Sea Drilling Project (DSDP) and the Ocean Drilling Program (ODP), this common depth is the meters composite depth (mcd) scale. Where overlapping recovery is available, the mcd scale is derived by 
stratigraphically correlating downhole variations in physical, chemical, and magnetic properties of the recovered sediments (see the "Sites M0001-M0004" chapter). Stratigraphic alignment results in core-specific offsets to the mbsf depth scale, which is determined during drilling by measuring the amount of drill pipe deployed from the rig floor. In the absence of overlapping recovery, the published mcd scale introduces offsets to prevent overlap between subsequent cores from the same hole. Core-specific offsets required to calculate meters composite depth from the mbsf depth are compiled in an "affine" table (see Table T25 in the "Sites M0001-M0004" chapter).

The construction of composite depth scales helps circumvent a host of potential errors that arise when developing a stratigraphic reference frame with centimeter-scale precision from depth measurements made while drilling hundreds of meters into the seafloor from a nonstationary platform. These errors can be associated with the original rig floor measurements of the mbsf depth, as well as with deviation of the drill string from an assumed vertical axis in both the borehole and intervening seawater. Similarly, material related to drilling disturbances and core deformation from drilling (flow-in, small-scale sloughing of the borehole walls, etc.) is included as part of the recovered core but does not necessarily reflect the stratigraphic progression of the sediments. At the most basic level, curatorial procedures introduce a bias into the mbsf depth scale by assuming that the top of the core corresponds to the top of the cored interval. When $<100 \%$ recovery is achieved, this can introduce substantial errors into the depth of a core. When recovery is $>100 \%$, material from subsequent cores overlaps when they are clearly not from the same stratigraphic position. A review of these and other factors associated with potential depth errors can be found in a number of DSDP and ODP publications (see Acton, Borton, et al., 2001, and references therein).

Unlike other ODP and IODP expeditions where multiple holes provide extensive overlapping recovery to facilitate the stratigraphic correlation procedure, ACEX only acquired overlapping recovery in the upper 30 mbsf (Fig. F2). Stratigraphically correlating this material proved difficult because of the large offsets encountered in near-surface sediments and the generally poor core quality. The highest quality cores came from holes where the advanced piston corer (APC) was successfully employed, in total eight cores. Alternatively, where the extended core barrel (XCB) was used to sample near-surface sediments, extensive core disturbance occurred.

Here we present a refinement to the published composite depth scale that alters offsets to cores in the uppermost 55 mbsf. Using additional data acquired from split cores and through the inclusion of two nearby cores collected from previous expeditions to the Lomonosov Ridge, the revised mcd (rmcd) scale more accurately reflects the true stratigraphic placement of the recovered material in the uppermost 55 mbsf and addresses uncertainties in the depths where there is either a lack of firm tie points or no overlapping recovery. Using the rmcd scale, we redefine the tie points for the spliced composite depth scale in the upper $27 \mathrm{rmcd}$ and propose a series of additional ties that are required to make centimeterscale adjustments to material from this interval that lies outside the spliced composite record.

\section{Initial composite record}

During ACEX, overlapping recovery in the near-surface sediments $(\sim 30 \mathrm{mbsf})$ was achieved through drilling at three of the four sites visited during the expedition (Sites M0002-M0004). Only a core catcher sample was recovered from Site M0001A, and this site is not included in any of the integrated depth scales. The seafloor was captured in a single core, 302-M0004C-1H, and is confirmed by the lithologic character and microfossil abundances found in the sediment at the top of this core (see the "Sites M0001-M0004" chapter). Although Core 302M0003A-1H was intended to sample material at the seafloor, clear stratigraphic ties indicate that the material in this core was recovered below 3.5 mbsf.

In the uppermost 18 mbsf, the published composite record relies on material from two holes (M0003A and M0004C) cored using the APC. Below 18 mbsf, a short interval from Core $302-\mathrm{M} 0004 \mathrm{~A}-1 \mathrm{H}$ is incorporated before a tie is made to Core 302-M0002A-6X. Following this tie, the composite record incorporates only material from Hole M0002A until the base of the hole at 280.69 mbsf (Core 302-M0002A-62X). The remainder of the composite section is from Hole M0004A (Fig. F2).

Below Core 302-M0002A-6X, partial overlap in the mbsf scales existed between Cores 302-M0004C-6X through 9X and 302-M0002A-6X through 9X. Although tentative correlations using the physical and chemical properties of these sediments were made and the resulting offsets incorporated into the published mcd scale, the accuracy of these ties is diminished by the following factors:

- Following excellent recovery in Cores 302M0004C-1H through $4 \mathrm{H}$, recovery in Cores $5 \mathrm{X}$, $6 \mathrm{X}$, and $7 \mathrm{X}$ was $15 \%, 61 \%$, and $0 \%$, respectively. This adds uncertainty to the true depths of Cores 302-M0004C-8X and 9X, which had 86\% and $61 \%$ recovery, respectively. 
- Although recovery in Cores 302-M0002A-6X through 9X was good $(>75 \%)$, these cores were severely affected by coring-induced disturbances. Of the $17.16 \mathrm{~m}$ recovered, visually disturbed intervals, tabulated when the cores were split (see Table T24 in the "Sites M0001-M0004" chapter), account for $11.18 \mathrm{~m}$, roughly $65 \%$ of the recovered material.

- Neither paleomagnetic inclination nor whole-core petrophysical measurements provide definitive ties between these cores, which is possibly related to the poor recovery and diminished core quality.

Despite these problems, the best efforts were made to tie these cores into the published composite depth scale through stratigraphic correlation. This resulted in a large offset $(4.57 \mathrm{~m})$ being applied to Core 302M0002A-7X. This offset was gradually diminished through the subsequent cores from Hole M0002A and was gone by Core 302-M0002A-14X. Below Core 302-M0002A-14X, offsets in the published composite depth scale are solely defined by the amount of recovery versus penetration. Unless $>100 \%$ recovery was acquired in the previous core, the tops of cores are assumed to be coeval with the top of the cored interval. However, when a core had $>100 \%$ recovery the subsequent core was shifted down to the base of the recovered interval. In the absence of overlapping recovery, the method adopted below Core 302M0002A-14X is a logical approach, keeping the composite depth scale as close to the original mbsf scale as possible.

\section{Logging data and absolute depth uncertainty}

When incomplete recovery plagues a drilling hole, a valuable constraint on the relative depths of cores can be obtained by integrating logging data with petrophysical measurements made on recovered sediments. This is most commonly achieved by migrating core depths onto an equivalent logging depth (eld) scale. During ACEX, logging was conducted in Hole M0004B, providing the opportunity to integrate downhole natural gamma radiation (NGR) and compressional wave ( $P$-wave) velocity measurements with similar data sets collected on whole cores (see the "Sites M0001-M0004" chapter).

Moderate-quality logging data were acquired on 2 passes between 210 and 65 mbsf. Offsets between the $P$-wave velocity (140-200 eld) and NGR measurements (155-180 eld), combined with the lithologically homogeneous character of Unit 1, make detailed integration of the core and logging depth scales problematic. The logging data do cross one of the largest changes in sediment physical properties encountered during ACEX. This transition occurs across lithologic Subunit 1.5, where a gradual progression is seen from fossil-poor glaciomarine deposits into biosiliceous and organic carbon-rich sediments (Moran et al., 2006). Subunit 1.5 is a $5.19 \mathrm{~m}$ long sequence defined by dramatic centimeter- to decimeter-scale, gray to black crosscutting couplets. The subunit extends from intervals 302-M0002A$44 \mathrm{X}-1,95 \mathrm{~cm}$ (192.94 mbsf), to $46 \mathrm{X}-1,113 \mathrm{~cm}$ (198.13 mbsf). The base of Subunit 1.5 marks a 26 m.y. hiatus separating Paleogene and Neogene sediments (Backman et al., 2008). It occurs in interval 302-M0002A-46X-1, $114 \mathrm{~cm}$, at $198.7 \mathrm{mcd}$ (equivalent to $198.14 \mathrm{mbsf}$ ).

In the petrophysics data, a drop in $P$-wave velocity and a corresponding peak in NGR mark the hiatus. Although the logging data do not capture the peak in NGR, as data acquisition ended prior to this depth being reached, the start of the increase in NGR seen in Cores 302-M0002A-44X and 45X is recorded in the logging data. Furthermore, positioning the sonic tool lower on the logging string allowed acquisition of sonic data deeper in the hole and appears to have captured the base of the subunit. A prominent feature in the sonic data is a $120 \mathrm{~m} / \mathrm{s}$ increase in compressional wave velocity at 200 eld. Below this increase, there are four recorded "down-stepping" features in the sonic log. Given that the associated rise in NGR was not captured in the logging data, the hiatus likely corresponds to the drop in $P$-wave velocity at 205 eld (Fig. F3). Within this framework, the increase in compressional wave velocity at 200 eld is associated with the gradual increase seen in Core 302-M0002A-44X that begins at the top of lithologic Subunit 1.5 and culminates with a peak $P$ wave velocity of $1691 \mathrm{~m} / \mathrm{s}$ at $193.85 \mathrm{mbsf}$ (Section 302-M0002A-44X-2, $35 \mathrm{~cm}$ ). However, this assumes that the depth separating Cores 302-M0002A-44X and $45 \mathrm{X}$ in the mbsf scale is accurate. If a larger gap exists between these cores, then the base of Subunit 1.5 could correspond to the drop in compressional wave velocity at 207 eld, or perhaps even lower, thereby extending the length of the transitional facies in Subunit 1.5.

The inferred ties between the core and logging data, bracketing the top and base of Subunit 1.5, can give a rough estimate of the accuracy of the mbsf depth scale. Errors in the mbsf depth scale related to inaccuracies in the rig floor measurement of pipe deployment are generally cumulative. Over the length of a hole they should not exceed the length of a drill pipe stand. Here the difference between the inferred logging depth to the base of lithologic Subunit 1.5 (205 eld) and its equivalent core depth (198.14 mbsf) is 
$6.86 \mathrm{~m}$. This difference approximates the cumulative downhole error in the mbsf depths. Considering that the logged site (M0004B) was $\sim 15 \mathrm{~km}$ from the cored site (M0002A), this error is not unreasonable.

\section{Evaluating the spliced record}

Prior to ACEX, a number of expeditions to the central Arctic Ocean recovered shallow-penetrating cores from the Lomonosov Ridge. These include two cores collected near the ACEX sites: Core 96/12-1PC, a $7.22 \mathrm{~m}$ long piston core recovered at $87.10^{\circ} \mathrm{N}$, $144.77^{\circ} \mathrm{W}$ in 1996 (Jakobsson et al., 2000, 2001, 2003), and Core PS-2185-6, a $7.68 \mathrm{~m}$ long core acquired using a square-barreled Kastenlot gravity corer from $87.53^{\circ} \mathrm{N}, 144.17^{\circ} \mathrm{W}$ (Fütterer, 1992) (Fig. F1). These cores have been extensively studied (Jakobsson et al., 2000, 2001, 2003) and integrated into pan-Arctic studies of paleoenvironmental change (Spielhagen et al., 2004). These cores provide an additional resource for stratigraphically aligning the near-surface material from ACEX.

Bulk density and magnetic inclination data from ACEX, Cores 96/12-1PC (courtesy of Martin Jakobsson, Stockholm University), and PS-2185-6 (available from www.pangaea.de/PangaVista) are shown in Figure F4. Despite the difference in depth scales, bulk density and magnetic inclination records from these three "sites" are remarkably similar. The most obvious observation is that, given the ties in Figure F4, sedimentation rates at Cores 96/12-1PC and PS2185-6 were substantially lower than at the ACEX sites. Thus, material spliced into the ACEX composite record is recovered at these other sites within a single core and can be used to assess the quality of the splicing process.

In the uppermost $10 \mathrm{mbsf}$, two regions of the published composite ACEX record appear to deviate from the piston cores. Both regions fall on tie points made in the splicing process, suggesting that the differences may be related to an error in the stratigraphic correlation procedure and the development of the mcd scale for ACEX (Fig. F4). Ideally, for the purpose of stratigraphic correlation, cores from adjacent holes are vertically offset so that the top of a core from "Hole B" falls midway between a core at an equivalent depth in "Hole A." This maximizes the amount of material for cross-correlation and avoids reliance on tie points that fall close to the ends of cores where disturbances are generally most pronounced. During ACEX the amount of overlap between Cores 302-M0003A-1H and $2 \mathrm{H}$ and Cores 302$\mathrm{M} 0004 \mathrm{C}-1 \mathrm{H}$ and $2 \mathrm{H}$ was negligible in both the mbsf and mcd scales (i.e., the top and base of Core 302$\mathrm{M} 0004 \mathrm{C}-2 \mathrm{H}$ closely correspond to the top and base of 302-M0003A-1H). Intervals containing discrepancies between the ACEX composite and records from the other piston cores correspond to intervals in the spliced record where two or more cores overlapped, but only at the very ends.

\section{Revised depth offsets}

Based upon these misalignments, the published composite splice has been revised, resulting in a better fit among the three records (Fig. F5; Tables T1, T2). One of the biggest changes occurs where Cores 302-M0004C-2H and $3 \mathrm{H}$ overlap with the base of Core $302-\mathrm{M} 0003 \mathrm{~A}-1 \mathrm{H}$. In the original mcd scale, Cores 302-M0004C-2H and $3 \mathrm{H}$ overlapped, and given that both had $>100 \%$ recovery, this was reasonable. However, the amount of overlap could not be unambiguously determined because Core 302M0003A-1H ended at a similar depth to Core 302$\mathrm{M} 0004 \mathrm{C}-2 \mathrm{H}$ and there was a gap before the start of Core 302-M0003A-2H (Fig. F6). Increasing the amount of overlap between Cores 302-M0004C-1H and $2 \mathrm{H}$ removed a short interval that contained both a density maximum and a negative geomagnetic feature that could not be reconciled with the stratigraphy of the neighboring cores. The removed feature also looked identical to one that sat immediately above it. Based on the following lines of evidence, it was decided that this was a splicing error:

- The interval could not be correlated with the stratigraphy in the neighboring sites.

- The interval occurred at a splice point with minimal overlap.

- The interval had the same magnetic and physical characteristics as a feature directly above it in the spliced record.

The error was corrected by increasing the overlap between Cores 302-M0004C-2H and 3H.

The revised offsets introduced in these shallow cores are carried over through Cores 302-M0004C-4H and $5 \mathrm{X}, 302-\mathrm{M} 0003 \mathrm{~A}-2 \mathrm{H}$ and $3 \mathrm{H}$, and the tie made to Core 302-M0004A-1H. Below Core 302-M0004A-1H a different approach was adopted in constructing the rmcd scale that results in differing offsets for Cores 302-M0002A-6X through 13X. Instead of relying on the material recovered from Hole M0002A, where $\mathrm{XCB}$ coring provided very poor recovery in the upper tens of meters beneath the seafloor, the composite section is extended to the base of Hole M0004A. This is possible because Cores 302-M0004A-1H, 2X, and $3 \mathrm{X}$ all partially overlap, implying duplicate recovery within the same hole. Again, an overall deterioration in core quality accompanied the switch to XCB for Cores 302-M0004A-2X and 3X, and the best 
available measurements for integrating these cores are environmental magnetic measurements and Xray fluorescence (XRF) scanning results from U-channel samples (see Figs. F7, F8, F9). Hence, a continuous composite section from the series of well-constrained ties to the top of Core 302-M0004A-1H can be extended to the base of Core 302-M0004A-3X at $26.69 \mathrm{rmcd}$.

Because of the uncertainty in the positions of shallow cores from Hole M0002A (Cores 302-M0002A$1 \mathrm{X}$ through $4 \mathrm{X}$ ), they are not included in the new spliced record and their original mcd depths are retained. However, the ties between Cores 302M0002A-5X and 6X with material from Hole M0004A were adjusted using results from XRF scanning of U-channel samples (Fig. F10). The new offsets for these cores are derived partially from the adjustments made to Cores 302-M0004A-2X and 3X and partially from the new ties linking these cores to the revised composite depth scale. Although these offsets provide the best estimate for the relative positions of these cores, their depths remain less constrained than the material above in Holes M0003A and M0004C. Based solely on the paleomagnetic inclination data (Fig. F7), the sections do not appear to be coeval; however, considering the other available data and accepting the poorer core quality and overall reduction in a clear paleomagnetic inclination record below $\sim 20 \mathrm{rmcd}$, these ties provide the best depth estimate currently available. Tying cores 302M0002A-5X and 6X into the revised composite depth scale is critical because below Core 302M0002A-6X material from this hole accounts for the remainder of the Neogene sediments included in the ACEX composite record. The new offsets for Cores 302-M0002A-5X and 6X place these cores 0.08 and $0.76 \mathrm{~m}$ deeper in the rmcd scale, respectively, than in the mcd scale (Table T1).

Following the adjustment to Core 302-M0002A-6X, the largest change in the revised offsets occurs at Core 302-M0002A-7X. Originally there was a $4.57 \mathrm{~m}$ offset applied to this core, which was difficult to reconcile with the high recovery seen in the surrounding cores (Table T1). Gradually this offset was removed, and the mcd scale was the same as the mbsf scale for cores deeper than Core 302-M0002A-14X. In the revised depth scale, no attempt is made to stratigraphically correlate Core 302-M0002A-7X with material from Cores 302-M0004C-8X and 9X. Instead, the top of Core 302-M0002A-7X is aligned with the base of Core 302-M00002A-6X. To do this requires an offset of $2.62 \mathrm{~m}$. Below Core 302M0002A-7X, this offset is gradually removed so that by Core 302-M0002A-9X the rmcd scale is the same as the mbsf scale.
The positions of Cores 302-M0004C-8X and 9X are poorly constrained, as they fall after a core with $0 \%$ recovery (302-M0004C-7X). In generating the mcd scale, Core 302-M0004C-6X was aligned with Core 302-M0002A-6X, and Cores 302-M0004C-8X and 9X were aligned to Cores 302-M0002A-7X and 8X, respectively. No further improvements were made to these ties, and in the rmcd scale the relative positions of these cores are maintained. Revisions to the mcd offsets of Cores 302-M0004C-6X, 8X, and 9X are determined by the coeval adjustments made to the corresponding cores in Hole M0002A.

Using the revised composite depth scale offsets, a new splice is developed for the upper 27 rmcd (Fig. F6; Table T2) that only incorporates material from Holes M0003A, M0004C, and M0004A. Although the spliced record extends to the base of the cored section, the first tie to Hole M0002A at $26.69 \mathrm{rmcd}$ marks the end of the "continuous spliced record." Because there is no overlapping recovery, there is no direct check on the stratigraphic positions of cores below Core 302-M0002A-6X, and the revised composite depths are determined by trying to maintain the closest match to the mbsf depths. Based upon the above discussion, it is also clear that no clear ties exist between Cores 302-M0002A-3X and 4X; 302M0004C-6X, 8X, and 9X; and 302-M0004B-1X and the composite spliced record, and any data taken from these cores must be used with caution.

\section{Regional integration}

The revised splice can be readily correlated with piston Cores 96/12-1PC and PS-2185-6 based on similarities in downhole variations in bulk density, magnetic susceptibility, and paleomagnetic inclination. To highlight the correlation between the sites, Core 96/12-1PC and PS-2185-6 data are migrated onto the rmcd scale of the ACEX composite. The projected bulk density profiles are exceptionally well correlated and can be corroborated by the alignment of prominent sedimentary features common at all sites (Fig. F11). These include a significant drop in the $>63 \mu \mathrm{m}$ size fraction that occurs at $4.65 \mathrm{rmcd}$ in the ACEX record and two peach-colored clay layers composed exclusively of very fine grained sediment (identified in the higher resolution grain size sampling in Core 96/12-1PC) (Jakobsson et al., 2001).

\section{Stretching and squeezing of material}

One of the advantages of using composite records is that they allow small-scale deformations and lateral 
heterogeneities in sediments from neighboring sites and holes to be recognized. The highest quality and most representative material available from the overlapping sections are then preferentially incorporated into the spliced record. However, in developing the composite depth scale and spliced record, a single tie is commonly used to align neighboring cores. This results in small-scale heterogeneities within depth equivalent cores remaining misaligned. The stretching and squeezing of material within any individual core to ultimately "tune" it to the composite record has traditionally been a separate step during ODP and IODP expeditions. Occasionally, this is done when the composite depth scale is converted to age or when it is integrated into an equivalent logging depth scale.

High-resolution studies of the ACEX material that falls within the uppermost 19 rmcd will need to account for these small offsets between coeval materials that cannot be accounted for by a single tie point. These adjustments to the rmcd scale only need to be made when integrating material that falls outside the spliced record (Table T2). The alignment of material from Holes M0003A and M0004C with the composite record from ACEX is shown in Figure F12, with the ties required to achieve optimal alignment through stretching and squeezing listed in Table T3. Between $\sim 19$ and $27 \mathrm{rmcd}$, only material from Hole M0004A is used in the revised composite splice, and no adjustments have been attempted for potentially overlapping material from Hole M0002A.

\section{Conclusions}

By integrating material recovered during ACEX with sediments recovered from neighboring piston cores, improvements to the composite depth scale have been made. In the revised composite depth scale the continuous undisturbed spliced record ends at the base of Section 302-M0004A-3X-2 (26.45 mcd, 26.69 rmcd). Above $19.33 \mathrm{mcd}$, where APC cores were collected, the maximum difference between the mcd and rmcd scale is $11 \mathrm{~cm}$. Below this point differences become larger, and depths for Cores 302-M0002A-7X through $13 \mathrm{X}$ are revised to bring them closer to their mbsf depths. The revised composite section can be accurately integrated with shallow penetrating piston cores collected on previous expeditions, providing a baseline for future studies that pool the resources and data available from all these central Arctic sites.

\section{Acknowledgments}

Financial support was provided by the National Science Foundation and the U.S. Science Support Program of Joint Oceanographic Institutions (JOI), Inc. (now renamed Consortium for Ocean Leadership). This research was conducted with samples and data from the Integrated Ocean Drilling Program (IODP), an international marine research program dedicated to advancing scientific understanding of the Earth, the deep biosphere, climate change, and Earth processes by sampling and monitoring subseafloor environments.

\section{References}

Acton, G.D., Borton, C.J., and the Leg 178 Shipboard Scientific Party, 2001. Palmer Deep composite depth scales for Leg 178 Sites 1098 and 1099. In Barker, P.F., Camerlenghi, A., Acton, G.D., and Ramsay, A.T.S. (Eds.), Proc. ODP, Sci. Results, 178: College Station, TX (Ocean Drilling Program), 1-35. doi:10.2973/

odp.proc.sr.178.202.2001

Backman, J., Jakobsson, M., Frank, M., Sangiorgi, F., Brinkhuis, H., Stickley, C., O’Regan, M., Løvlie, R., Pälike, H., Spofforth, D., Gattacecca, J., Moran, K., King, J., and Heil, C., 2008. Age model and core-seismic integration for the Cenozoic Arctic Coring Expedition sediments from the Lomonosov Ridge. Paleoceanography, 23(1):PA1S03. doi:10.1029/2007PA001476

Fütterer, D.K., 1992. ARCTIC '91: the expedition ARK VIII/ 3 of RV Polarstern in 1991. Ber. Polarforsch., 107:1-267.

Jakobsson, M., Backman, J., Murray, A., and Løvlie, R., 2003. Optically stimulated luminescence dating supports central Arctic Ocean cm-scale sedimentation rates. Geochem., Geophys., Geosyst., 4(2):1016. doi:10.1029/ 2002GC000423

Jakobsson, M., Løvlie, R., Al-Hanbali, H., Arnold, E., Backman, J., and Mörth, M., 2000. Manganese and color cycles in Arctic Ocean sediments constrain Pleistocene chronology. Geology, 28(1):23-26. doi:10.1130/ 0091-7613(2000)28<23:MACCIA >2.0.CO;2

Jakobsson, M., Løvlie, R., Arnold, E.M., Backman, J., Polyak, L., Knudsen, J.-O., and Musatov, E., 2001. Pleistocene stratigraphy and paleoenvironmental variation from Lomonosov Ridge sediments, central Arctic Ocean. Global Planet. Change, 31(1-4):1-22. doi:10.1016/S0921-8181(01)00110-2

Jokat, W., Weigelt, E., Kristoffersen, Y., Rasmussen, T., and Schöne, T., 1995. New geophysical results from the south-western Eurasian Basin (Morris Jesup Rise, Gakkel Ridge, Yermak Plateau) and the Fram Strait. Geophys. J. Int., 123(2):601-610. doi:10.1111/j.1365-

246X.1995.tb06874.x 
Moran, K., Backman, J., Brinkhuis, H., Clemens, S.C., Cronin, T., Dickens, G.R., Eynaud, F., Gattacceca, J., Jakobsson, M., Jordan, R.W., Kaminski, M., King, J., Koç, N., Krylov, A., Martinez, N., Matthiessen, J., McInroy, D., Moore, T.C., Onodera, J., O’Regan, M., Pälike, H., Rea, B., Rio, D., Sakamoto, T., Smith, D.C., Stein, R., St. John, K., Suto, I., Suzuki, N., Takahashi, K., Watanabe, M., Yamamoto, M., Farrell, J., Frank, M., Kubik, P., Jokat, W., and Kristoffersen, Y., 2006. The Cenozoic palaeoenvironment of the Arctic Ocean. Nature (London, U. K.), 441(7093):601-605. doi:10.1038/nature04800

Sakamoto, T., Kuroki, K., Sugawara, T., Aoike, K., Iijima, K., and Sugisaki, S., 2006. Non-destructive X-ray fluores- cence (XRF) core-imaging scanner, TATSCAN-F2. Sci. Drill., 2:37-9.

Spielhagen, R.F., Baumann, K.-H., Erlenkeuser, H., Nowaczyk, N.R., Nørgaard-Pedersen, N., Vogt, C., and Weiel, D., 2004. Arctic Ocean deep-sea record of northern Eurasian ice sheet history. Quat. Sci. Rev., 23(11-13):14551483. doi:10.1016/j.quascirev.2003.12.015

Initial receipt: 24 September 2007

Acceptance: 11 March 2008

Publication: 17 June 2008

MS 302-202 
Figure F1. Locations of sites visited during Expedition 302 and Cores 96/12-1PC and PS-2185-6. ACEX = Arctic Coring Expedition.

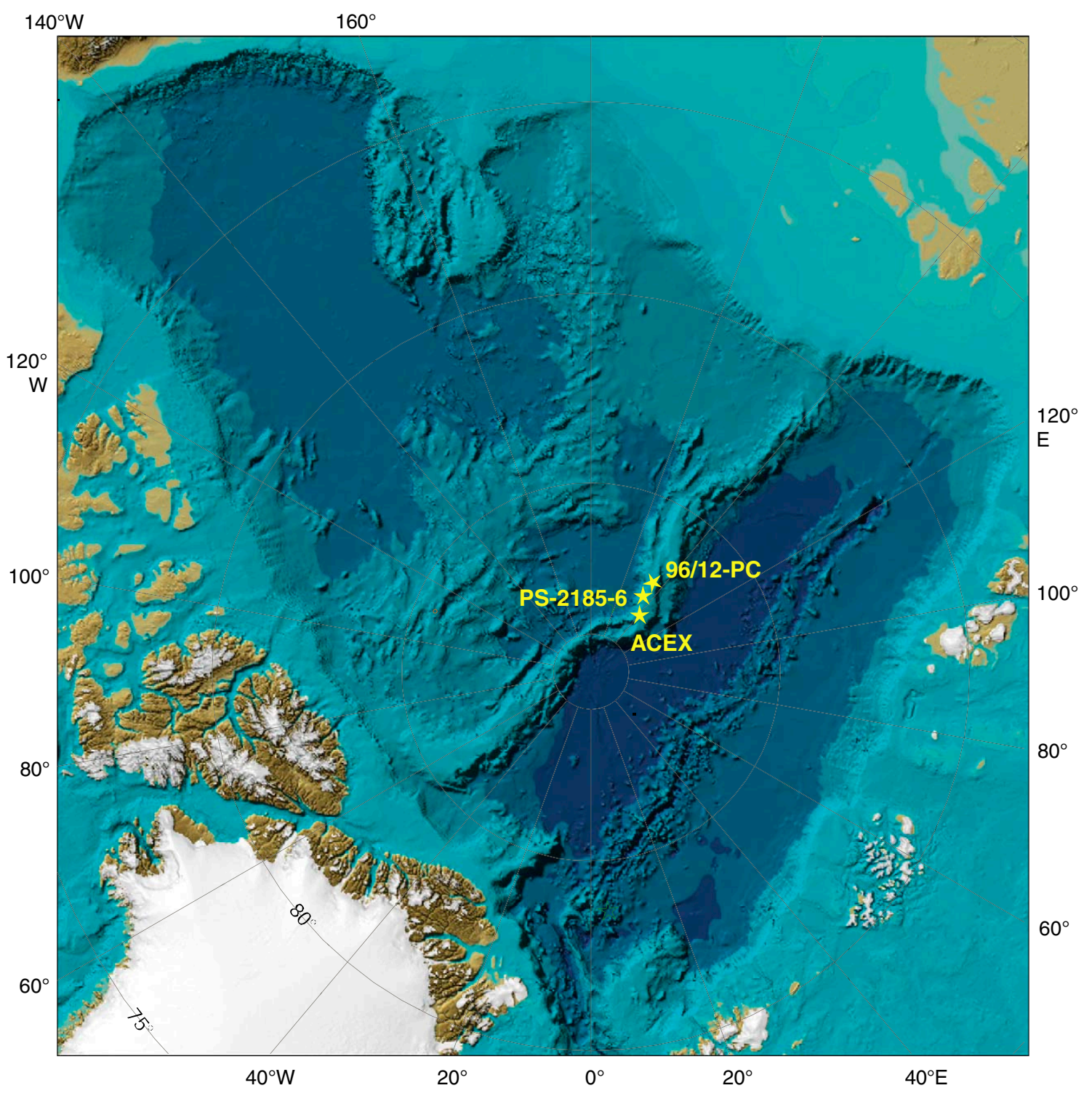


Figure F2. Core recovery for all Expedition 302 holes. Black = recovered core, white $=$ no core recovery, shaded = washed intervals (from the "Expedition 302 summary" chapter).

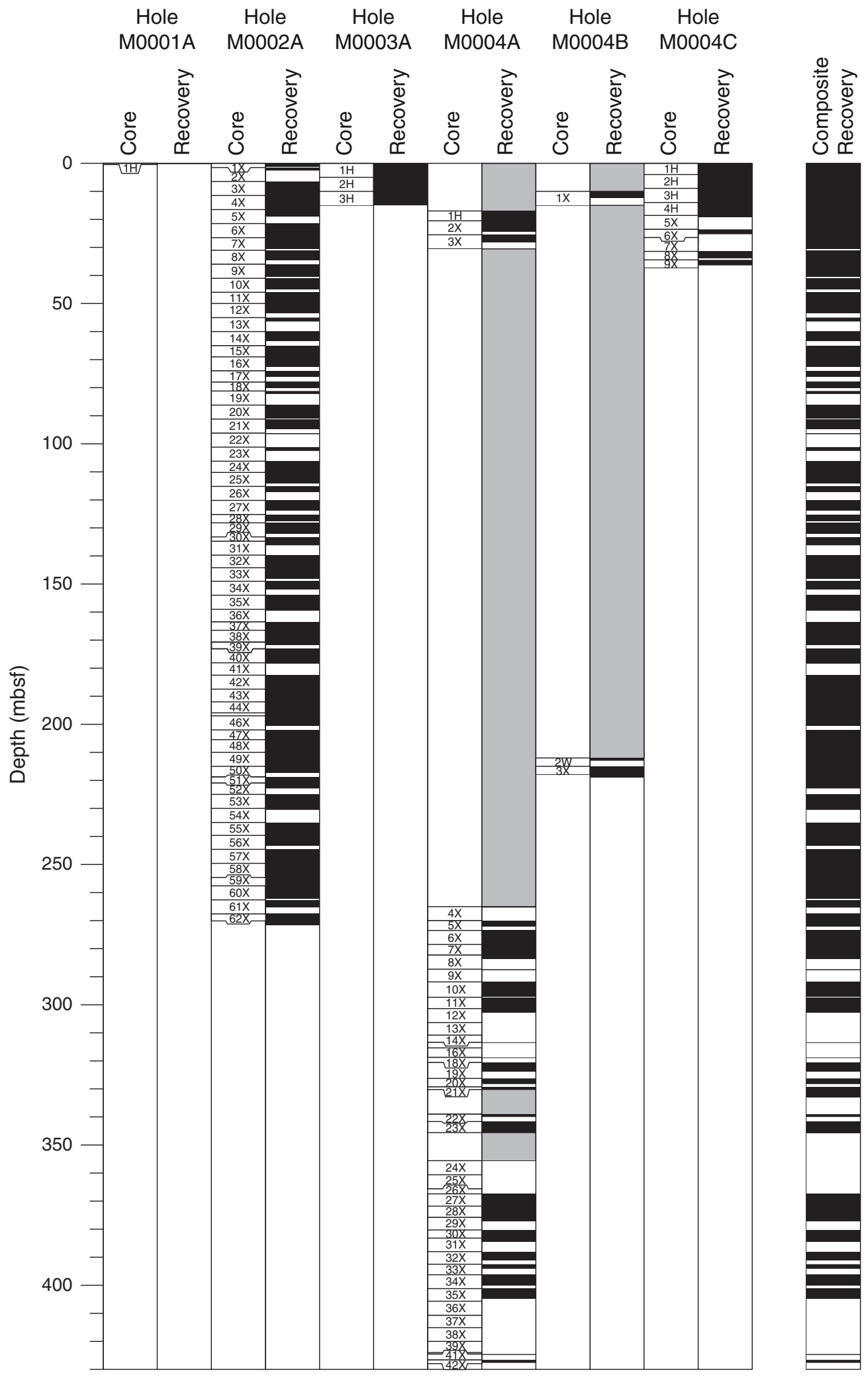


Figure F3. Core and logging measurements of $P$-wave velocity and natural gamma radiation (NGR) showing likely tie for the base of lithologic Subunit 1.5 . eld = equivalent logging depth. $P$-wave velocity measured shipboard on whole cores except the "brown" colored measurements acquired on split cores during the sampling party in Bremen. Core measurements in vicinity of the proposed tie are superimposed on the logging data to highlight the fit. Black lines = pass 1 logging data, gray lines = pass 2 logging data.

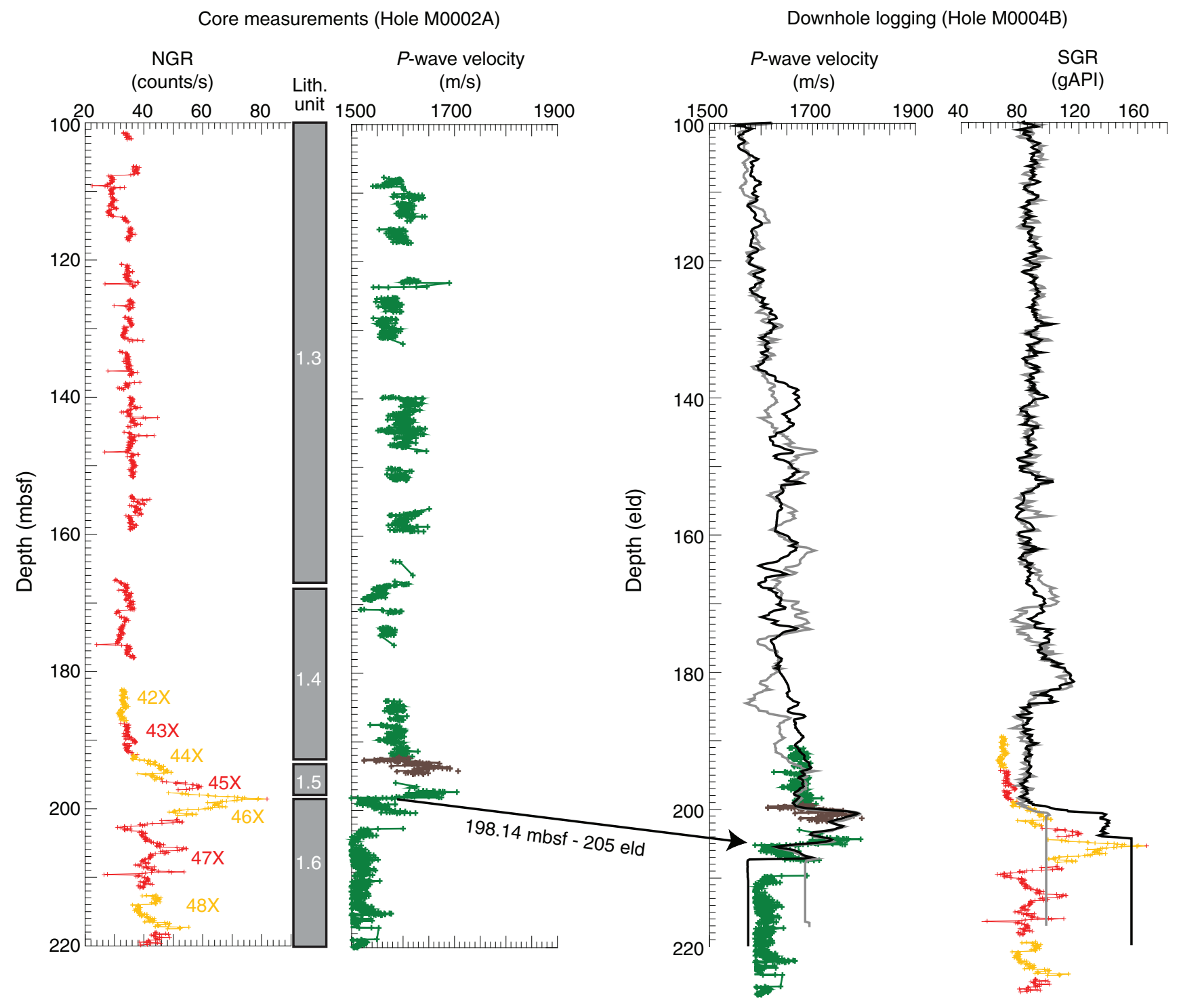


Figure F4. Paleomagnetic inclination and bulk density records from the ACEX composite section and Cores 96/ 12-1PC and PS-2185-6. ACEX data displayed using the offsets and tie points obtained from expedition results (see Tables T25 and T26 in the "Sites M0001-M0004" chapter). Arrows = position of tie points. Yellow boxes = regions where ACEX composite record deviates from stratigraphic successions recovered in neighboring cores. Dotted lines $=$ similar sequences between the records.

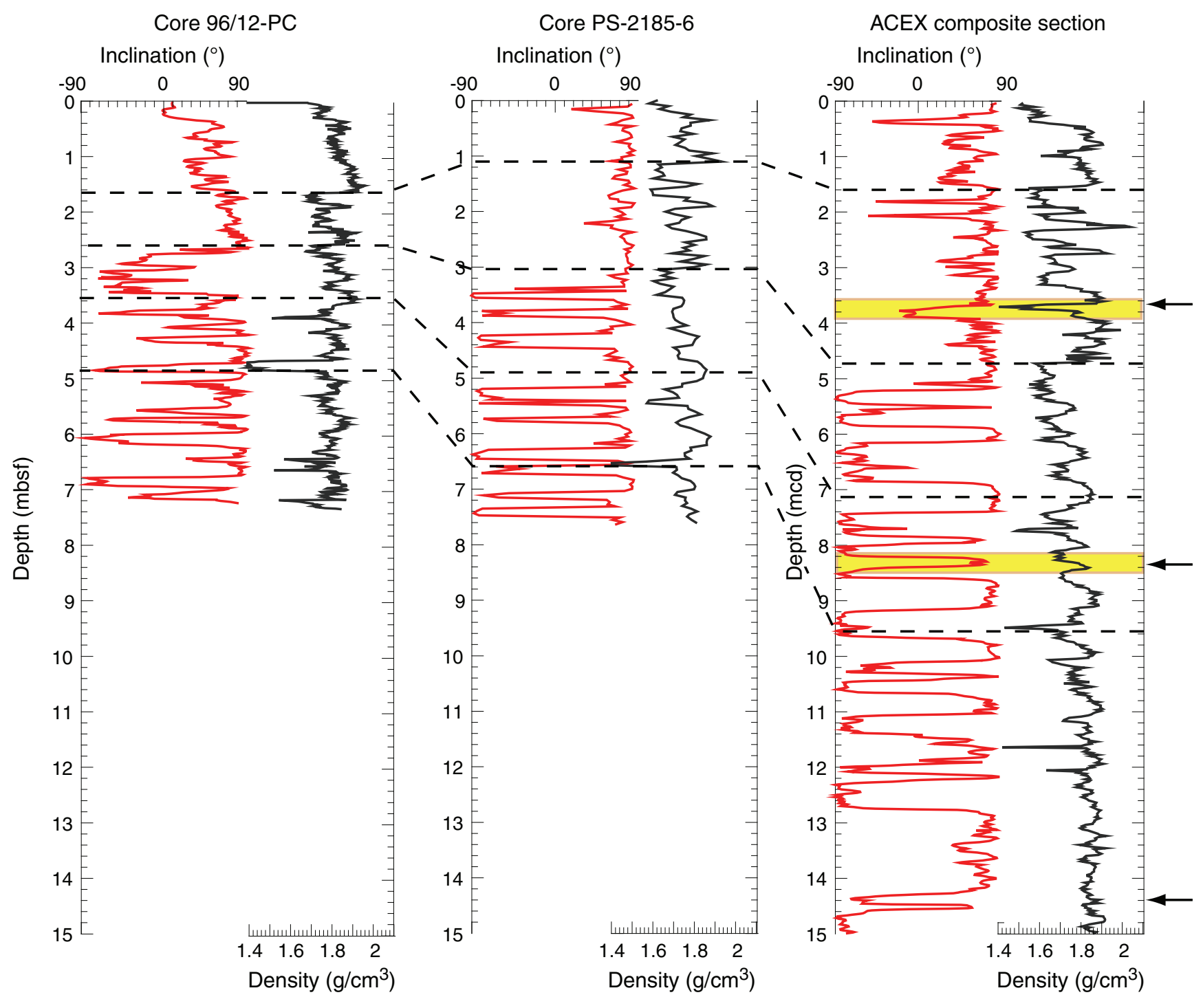


Figure F5. Paleomagnetic inclination and bulk density records from the ACEX composite section and Cores 96/ 12-1PC and PS-2185-6. ACEX data displayed using revised offsets and tie points (Tables T2 and T3). Dotted lines = similar sequences between the records.

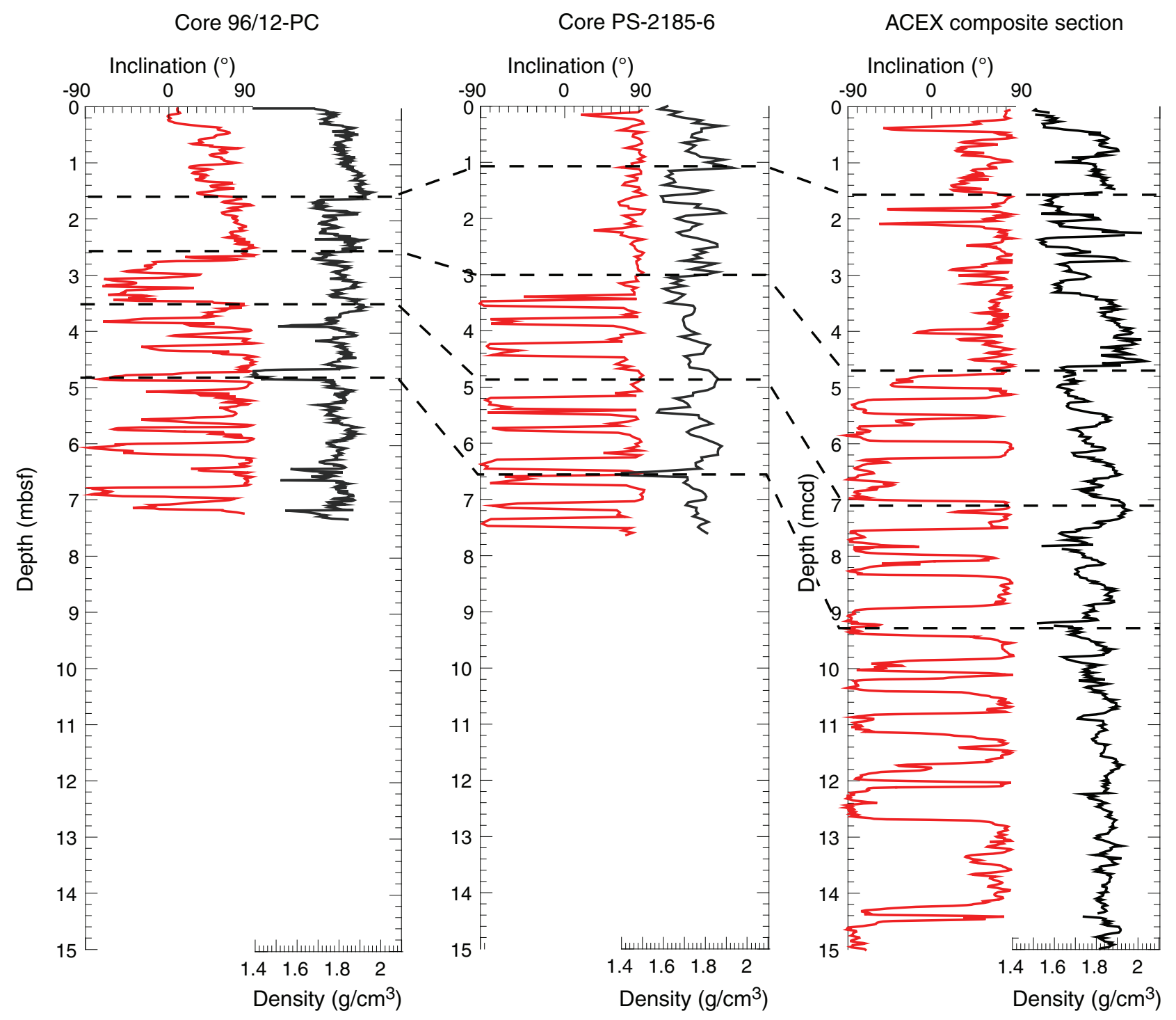


Figure F6. Original and revised splice trails. Red line = "trail" of material included in composite spliced section across the bulk density records from Holes M0003A, M0004C, and M0004A. A. Original splice and offsets. B. Revised splice and offsets.

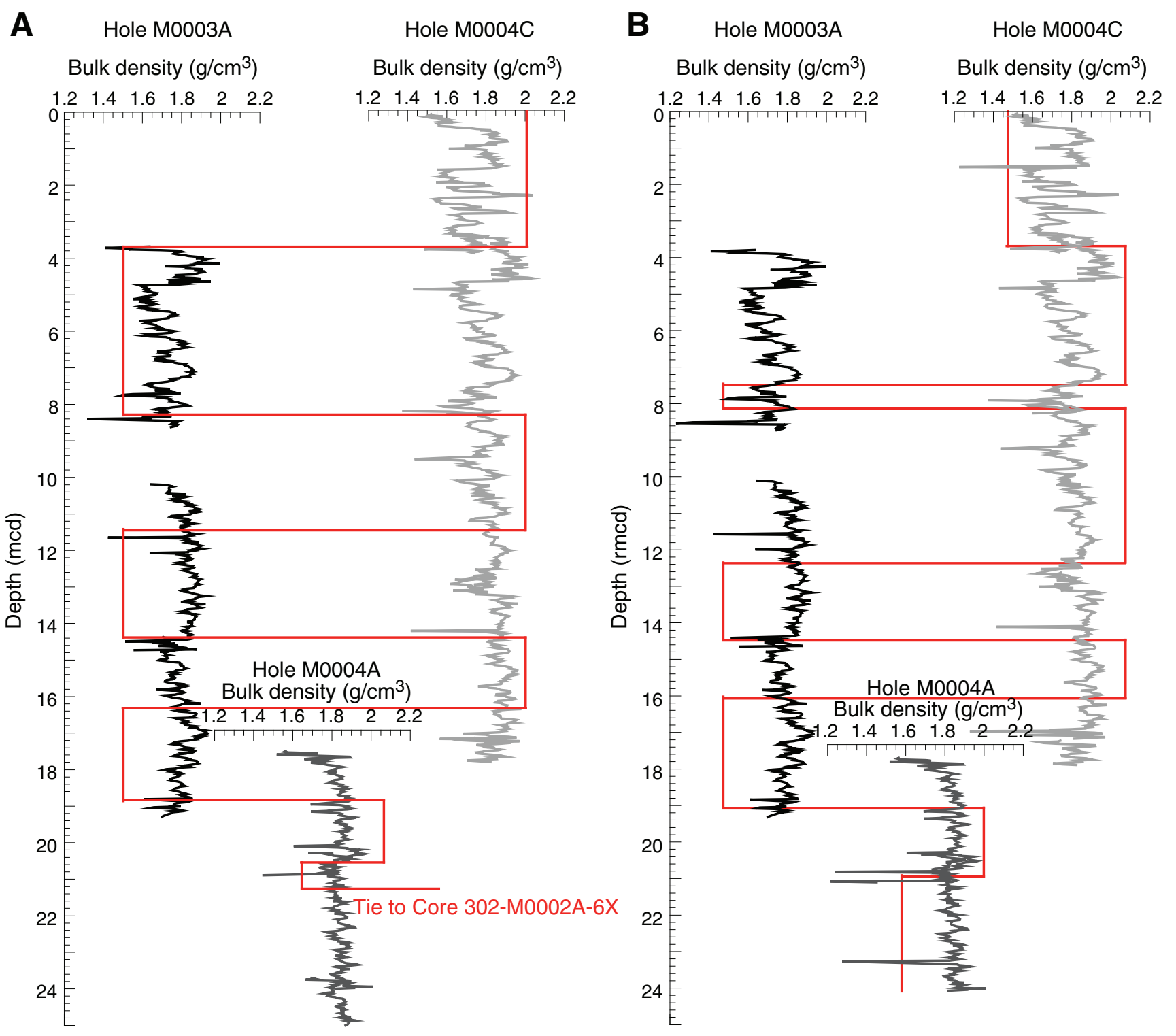


Figure F7. Inclination records after $55 \mathrm{mT}$ AF demagnetization for cores in the uppermost 40 rmcd in Holes M0002A, M0003A, M0004A and M0004C. Light green coloring applied to Core 302-M0004A-2X illustrates overlap with Cores $1 \mathrm{H}$ and $3 \mathrm{X}$.

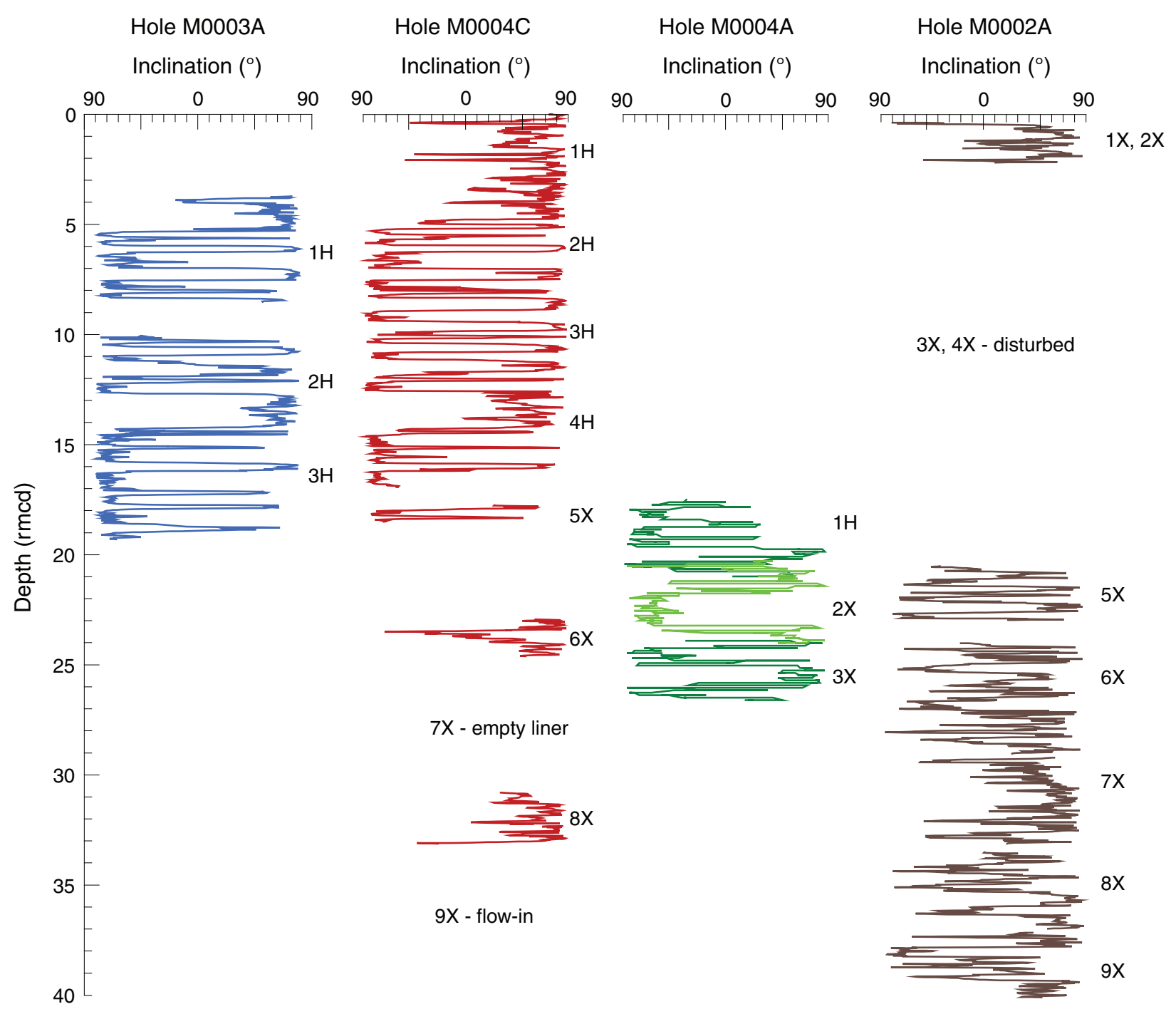


Figure F8. Anhysteretic remnant magnetization (ARM) of U-channel samples from Holes M0002A, M0003A, M0004A, and M0004C. ARM measurements were conducted at the Paleomagnetic Laboratory, University of Rhode Island, using a 2-G Enterprises small-access cryogenic magnetometer and imparted in a $100 \mathrm{mT}$ alternating field while in the presence of a $100 \mu \mathrm{T}$ direct field. Light green coloring applied to Core 302-M0004A$2 \mathrm{X}$ illustrates overlap with Cores $1 \mathrm{H}$ and $3 \mathrm{X}$.

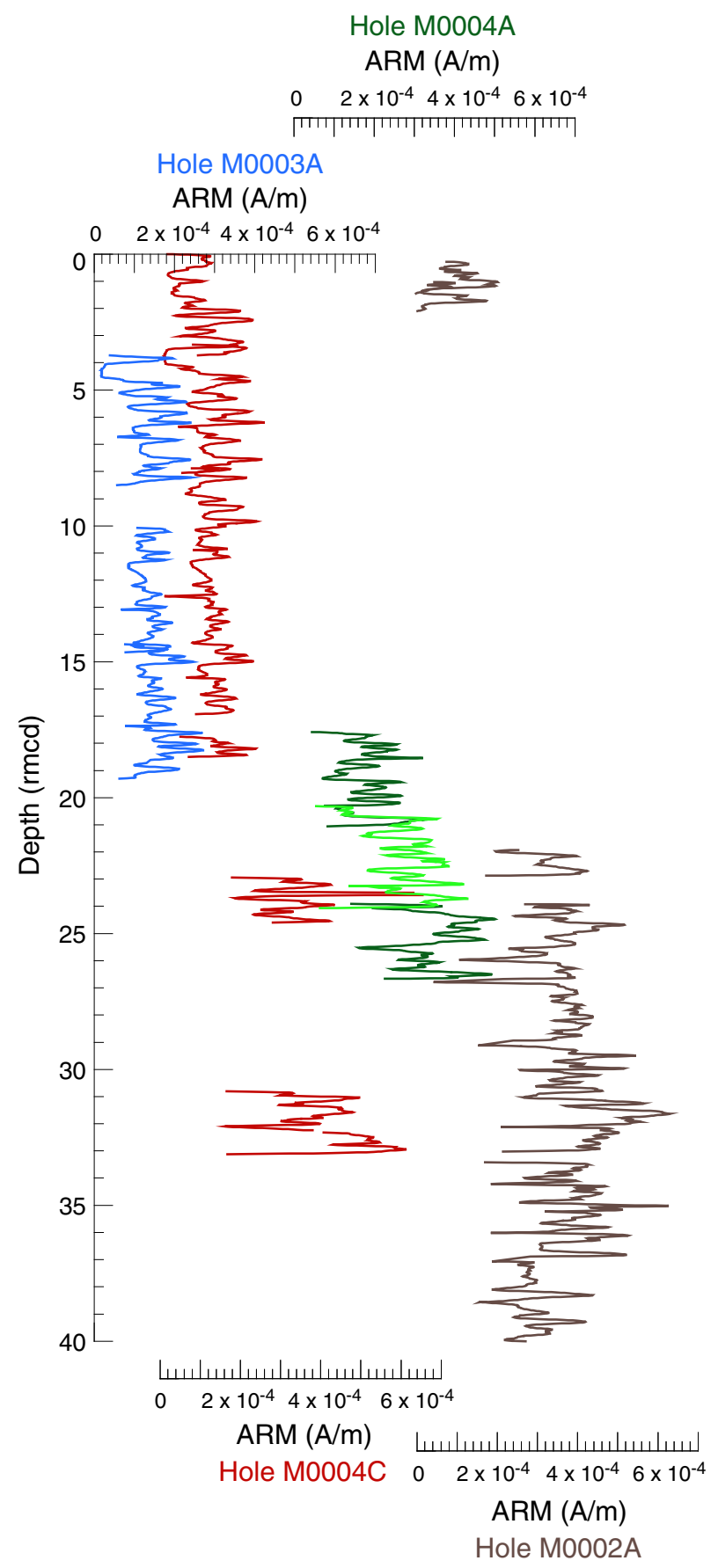


Figure F9. $\mathrm{Fe}_{2} \mathrm{O}_{3}$ concentrations in the uppermost 40 rmcd measured on U-channel samples using a nondestructive X-ray fluorescence scanner (TATSCAN-F2, IFREE/JAMSTEC) (Sakamoto et al., 2006) illustrating alignment of features between Holes M0002A, M0003A, M0004A and M0004C. Light green coloring applied to Core 302-M0004A-2X illustrates overlap with Cores $1 \mathrm{H}$ and $3 \mathrm{X}$.

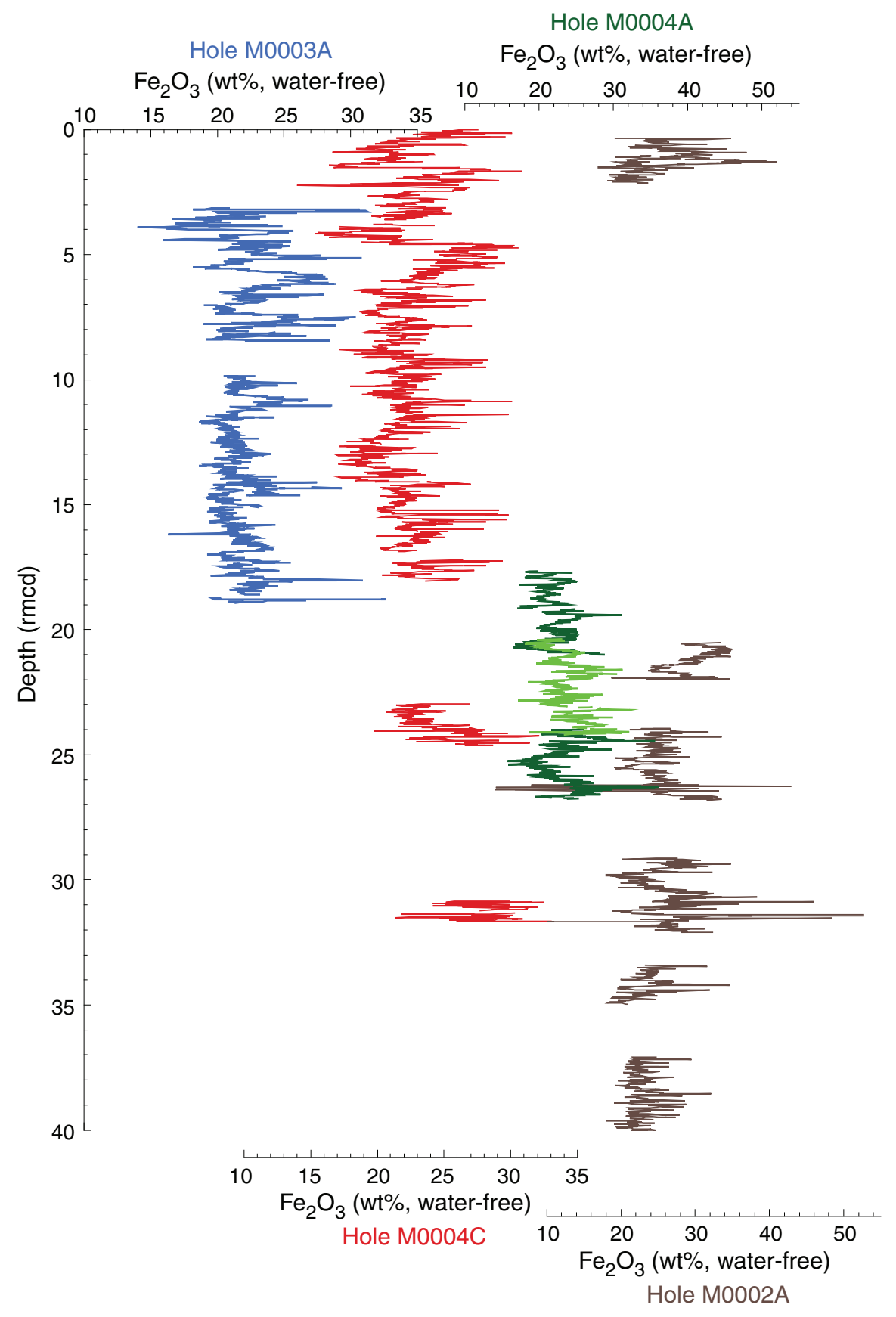


Figure F10. Elemental $\mathrm{Fe}_{2} \mathrm{O}_{3}$ profiles used to modify tie points of Cores 302-M0002A-5X and 6X into material from Hole M0004A. Original mcd scale is shown with similar features aligned in the rmcd scale connected with orange lines.

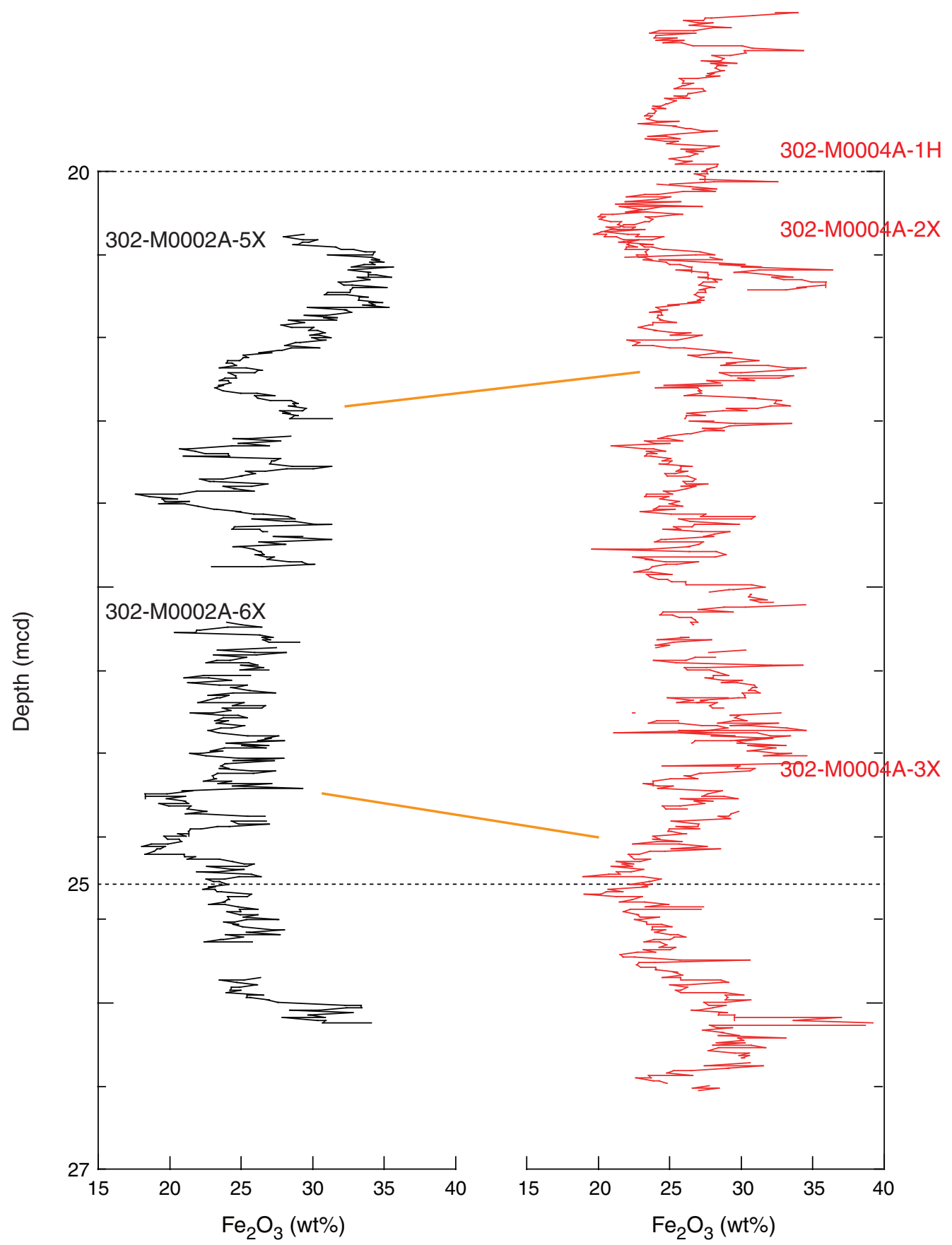


Figure F11. Stacked bulk density and paleomagnetic inclination data from ACEX composite section and Cores 96/12-1PC and PS-2185-6. Data from Cores 96/12-1PC and PS-2185-6 were migrated onto the ACEX rmcd scale using the ties from Table T4 after being stratigraphically correlated using physical property records. Coarse fraction content from Core 96/12-1PC is displayed to highlight the relationship between bulk density and grain size and illustrate the drop in coarse fraction content that occurs at $4.65 \mathrm{rmcd}$ in all the records. Yellow and pink lines $=$ prominent lithologic features.

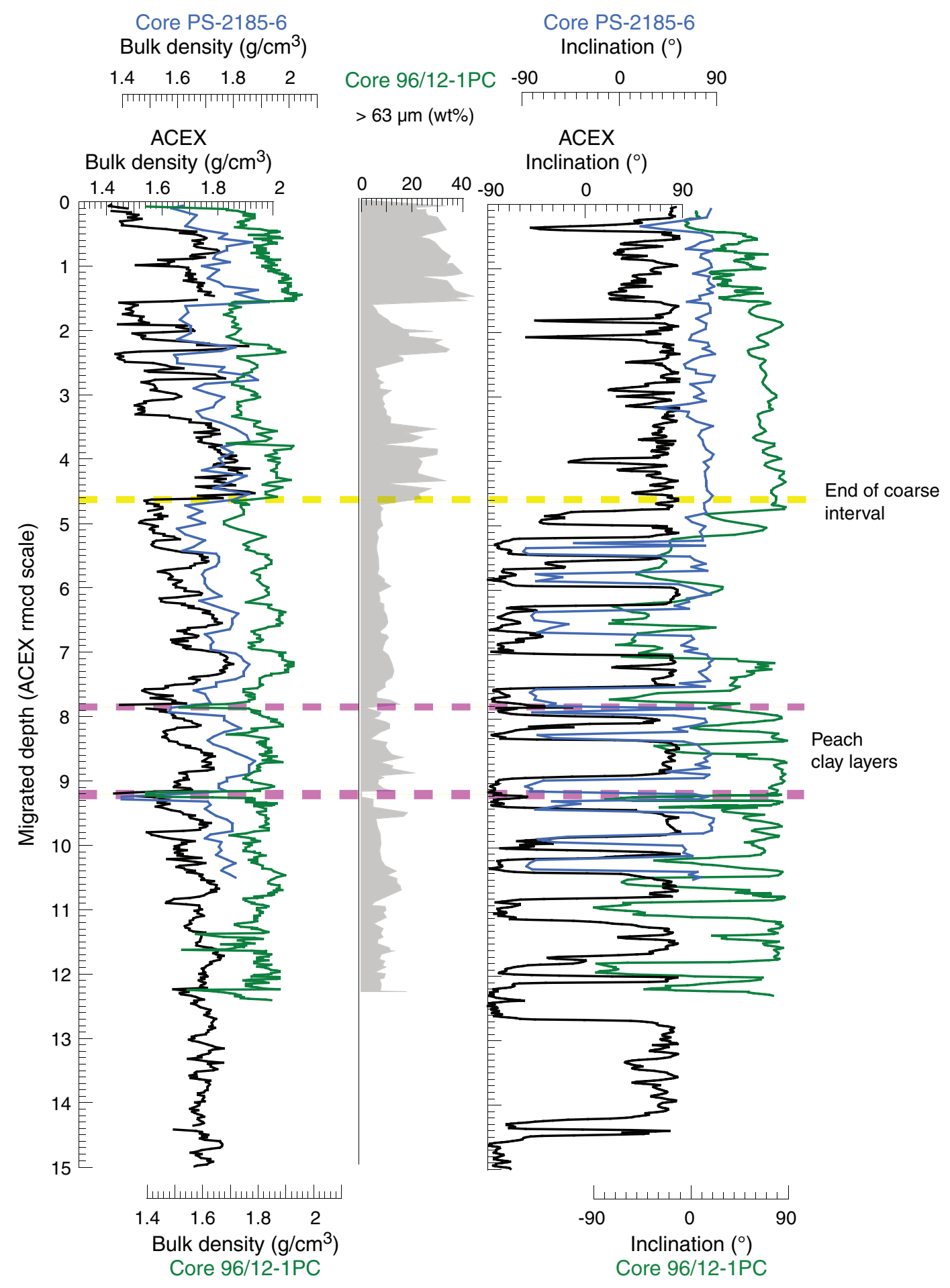


Figure F12. Tuning the rmcd depths. A. Bulk density records from Sites M0003A (red) and M0004C (blue) shown against the composite section in rmcd. Small offsets in the data can be seen where material from either site lies outside the splice trail. B. Bulk density, paleomagnetic inclination, and color reflectance $\left(\mathrm{a}^{\star}\right)$ values for Holes M0003A (red), M0004C (blue), and M0004A (green) displayed offset from the composite records. These records have been tuned to get the best fit between the material outside the splice trail and the composite splice. Ties for this tuning are given in Table T3.

A

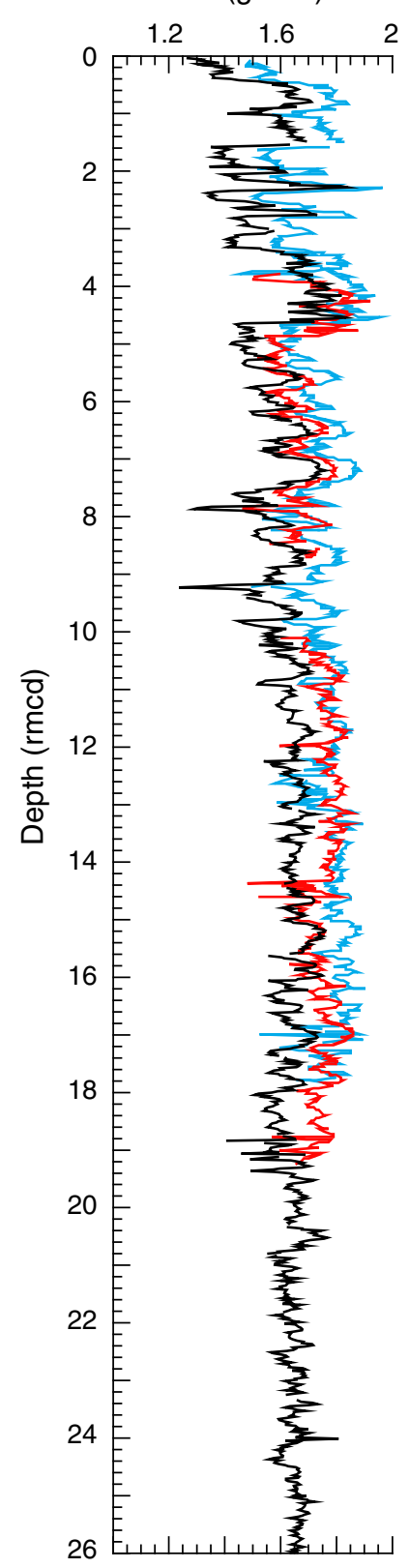

B

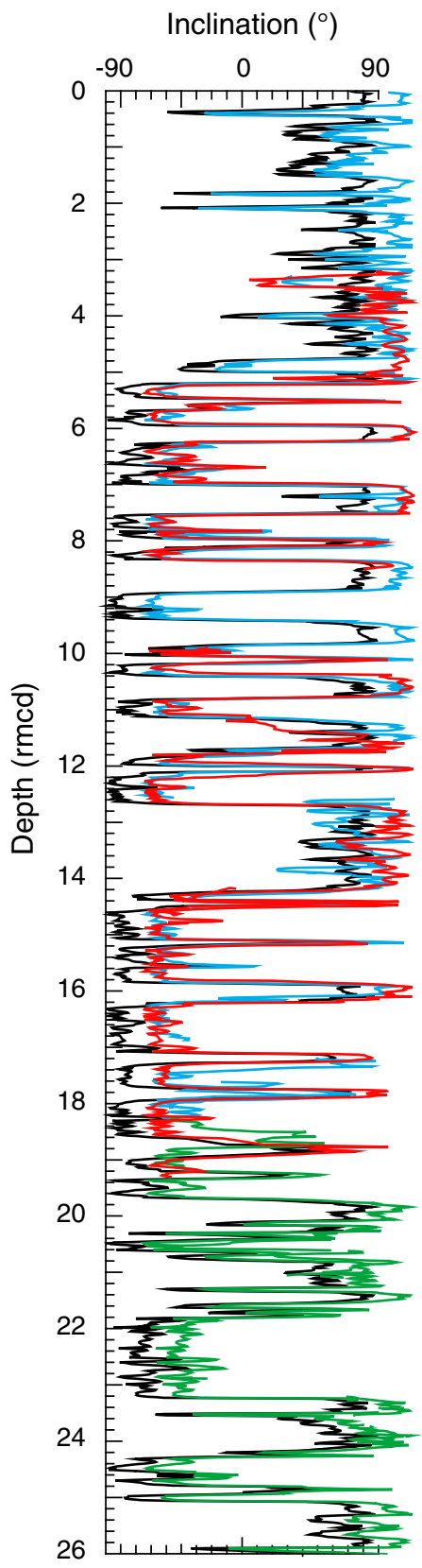

Bulk density $\left(\mathrm{g} / \mathrm{cm}^{3}\right)$

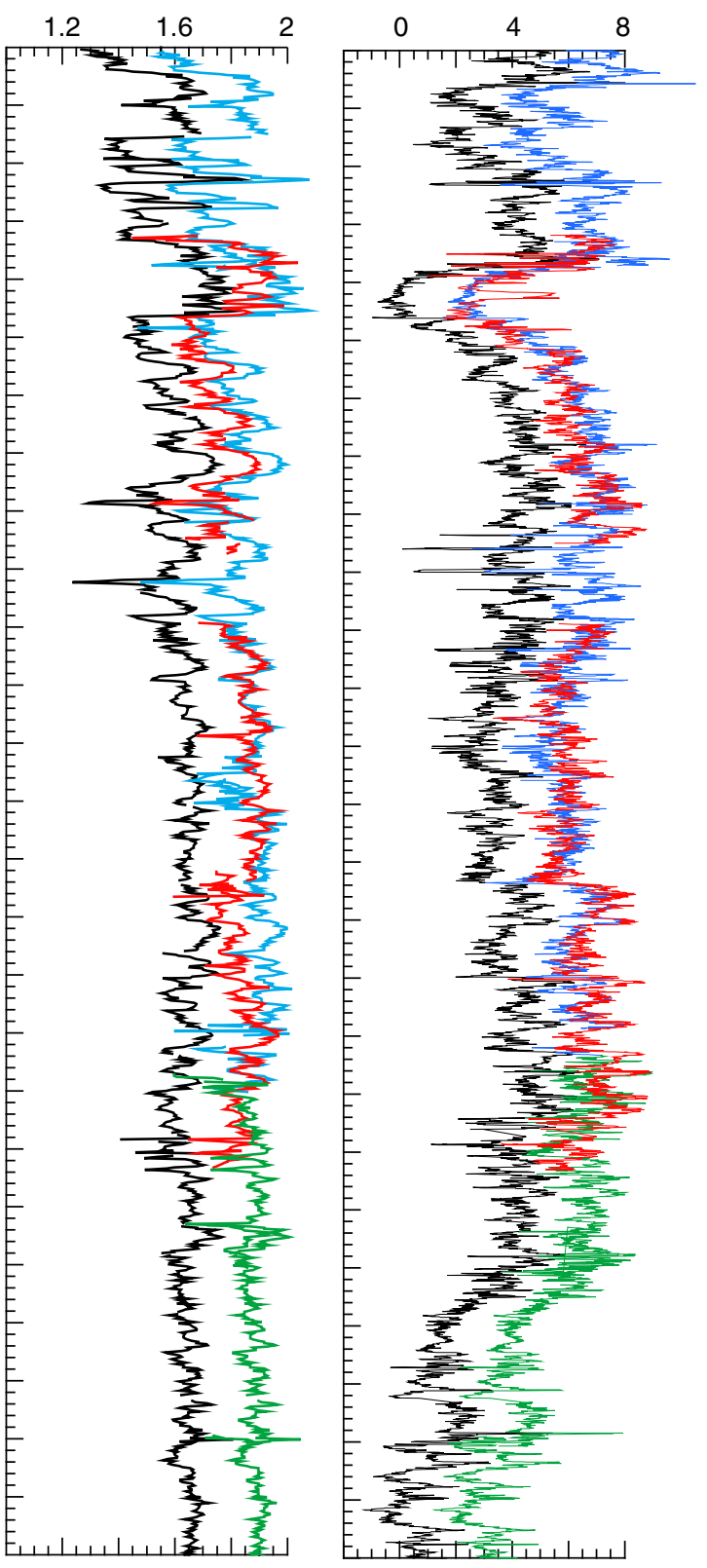


Table T1. Core recovery summary and vertical core offsets (affine) for the meters composite depth and revised meters composite depth scales, Holes M0002A, M0003A, M0004A, M0004B, and M0004C. (See table notes.) (Continued on next page.)

\begin{tabular}{|c|c|c|c|c|c|c|}
\hline Core & $\begin{array}{l}\text { Length } \\
\text { cored } \\
\text { (m) }\end{array}$ & $\begin{array}{l}\text { Length } \\
\text { recovered } \\
\text { (m) }\end{array}$ & $\begin{array}{l}\text { Recovery } \\
(\%)\end{array}$ & $\begin{array}{c}\text { Top of core } \\
\text { (mbsf) }\end{array}$ & $\begin{array}{l}\text { Offsets for } \\
\text { mcd scale } \\
\quad(\mathrm{m})\end{array}$ & $\begin{array}{l}\text { Offsets for } \\
\text { rmcd scale } \\
\text { (m) }\end{array}$ \\
\hline \multicolumn{7}{|l|}{$302-$} \\
\hline M0004A-1H & 5.00 & 3.50 & 70 & 17.00 & 0.37 & 0.58 \\
\hline M0004A-2X & 3.50 & 3.70 & 106 & 20.50 & -0.26 & -0.19 \\
\hline M0004A-3X & 5.00 & 2.79 & 56 & 25.50 & -1.83 & -1.59 \\
\hline M0004A-4X & 5.00 & 0.33 & 7 & 265.00 & 0.00 & 0.00 \\
\hline M0004A-5X & 3.50 & 2.11 & 60 & 270.00 & 0.00 & 0.00 \\
\hline M0004A-6X & 5.00 & 5.28 & 106 & 273.50 & 0.00 & 0.00 \\
\hline M0004A-7X & 3.80 & 5.18 & 136 & 278.50 & 0.20 & 0.20 \\
\hline M0004A-8X & 5.00 & 0.28 & 6 & 282.30 & 4.00 & 4.00 \\
\hline M0004A-9X & 4.50 & 0.36 & 8 & 287.30 & 0.00 & 0.00 \\
\hline M0004A-10X & 5.40 & 5.34 & 99 & 291.80 & 0.00 & 0.00 \\
\hline M0004A-11X & 4.05 & 5.43 & 134 & 286.80 & 0.00 & 0.00 \\
\hline M0004A-12X & 5.00 & 0.20 & 4 & 301.30 & 0.00 & 0.00 \\
\hline M0004A-13X & 4.50 & 0.00 & 0 & 306.30 & 0.00 & 0.00 \\
\hline M0004A-14X & 2.50 & 0.00 & 0 & 310.80 & 0.00 & 0.00 \\
\hline M0004A-15X & 2.00 & 0.26 & 13 & 313.30 & 0.00 & 0.00 \\
\hline M0004A-16X & 3.45 & 0.00 & 0 & 315.30 & 0.00 & 0.00 \\
\hline M0004A-17X & 0.01 & 0.00 & 0 & 318.80 & 0.00 & 0.00 \\
\hline M0004A-18X & 0.01 & 0.16 & 0 & 318.80 & 0.00 & 0.00 \\
\hline M0004A-19X & 6.00 & 3.17 & 53 & 320.53 & 0.00 & 0.00 \\
\hline M0004A-20X & 3.00 & 2.00 & 67 & 329.28 & 0.00 & 0.00 \\
\hline M0004A-21X & 0.90 & 3.59 & 399 & 333.18 & 0.00 & 0.00 \\
\hline M0004A-22X & 2.60 & 0.98 & 38 & 339.00 & 0.00 & 0.00 \\
\hline M0004A-23X & 4.00 & 4.07 & 102 & 341.60 & 0.00 & 0.00 \\
\hline M0004A-24X & 4.50 & 0.00 & 0 & 355.90 & 0.00 & 0.00 \\
\hline M0004A-25X & 5.00 & 0.00 & 0 & 360.40 & 0.00 & 0.00 \\
\hline M0004A-26X & 2.00 & 0.00 & 0 & 365.40 & 0.00 & 0.00 \\
\hline M0004A-27X & 4.40 & 4.85 & 110 & 367.40 & 0.00 & 0.00 \\
\hline M0004A-28X & 4.00 & 5.23 & 131 & 371.80 & 0.47 & 0.47 \\
\hline M0004A-29X & 4.00 & 1.32 & 33 & 375.80 & 2.00 & 2.00 \\
\hline M0004A-30X & 4.50 & 4.24 & 94 & 380.30 & 0.00 & 0.00 \\
\hline M0004A-31X & 2.90 & 0.55 & 19 & 383.20 & 1.50 & 1.50 \\
\hline M0004A-32X & 4.80 & 3.04 & 63 & 388.00 & 0.00 & 0.00 \\
\hline M0004A-33X & 4.50 & 1.65 & 37 & 392.50 & 0.00 & 0.00 \\
\hline M0004A-34X & 3.50 & 3.89 & 111 & 396.00 & 0.00 & 0.00 \\
\hline M0004A-35X & 5.20 & 3.59 & 69 & 401.20 & 0.00 & 0.00 \\
\hline M0004A-36X & 4.50 & 0.00 & 0 & 405.70 & 0.00 & 0.00 \\
\hline M0004A-37X & 5.00 & 0.00 & 0 & 410.70 & 0.00 & 0.00 \\
\hline M0004A-38X & 4.40 & 0.00 & 0 & 415.10 & 0.00 & 0.00 \\
\hline M0004A-39X & 4.90 & 0.20 & 4 & 420.00 & 0.00 & 0.00 \\
\hline M0004A-40X & 0.50 & 0.00 & 0 & 424.00 & 0.00 & 0.00 \\
\hline M0004A-41X & 2.10 & 0.33 & 16 & 424.50 & 0.00 & 0.00 \\
\hline M0004A-42X & 1.40 & 1.50 & 107 & 426.60 & 0.00 & 0.00 \\
\hline M0004B-1X & 5.00 & 2.31 & 46 & 10.00 & 0.16 & 0.16 \\
\hline M0004B-2X & 0.00 & 0.00 & 0 & Wash core & & \\
\hline M0004B-3X & 5.00 & 4.02 & 80 & 215.00 & 0.00 & 0.00 \\
\hline M0004C-1H & 4.50 & 3.91 & 87 & 0.00 & 0.00 & 0.00 \\
\hline $\mathrm{M} 0004 \mathrm{C}-2 \mathrm{H}$ & 4.50 & 4.95 & 110 & 4.00 & -0.65 & -0.66 \\
\hline M0004C-3H & 4.50 & 5.02 & 112 & 8.95 & -0.81 & -1.08 \\
\hline M0004C-4H & 4.50 & 4.64 & 103 & 13.97 & -1.29 & -1.38 \\
\hline M0004C-5X & 5.00 & 0.75 & 15 & 18.60 & -1.48 & -0.81 \\
\hline M0004C-6X & 2.83 & 1.72 & 61 & 23.60 & -0.67 & 0.09 \\
\hline M0004C-7X & 5.00 & 0.00 & 0 & 26.43 & 0.00 & 0.00 \\
\hline M0004C-8X & 3.00 & 2.42 & 81 & 31.43 & 1.44 & -0.51 \\
\hline M0004C-9X & 2.90 & 1.96 & 68 & 34.43 & 1.39 & -0.76 \\
\hline M0003A-1H & 4.50 & 5.05 & 112 & 0.00 & 3.62 & 3.73 \\
\hline M0003A-2H & 4.50 & 4.75 & 106 & 5.00 & 5.15 & 5.07 \\
\hline M0003A-3H & 5.00 & 5.00 & 100 & 9.50 & 4.33 & 4.36 \\
\hline M0002A-1X & 1.50 & 1.28 & 85 & 0.00 & 0.28 & 0.28 \\
\hline M0002A-2X & 5.00 & 1.08 & 22 & 1.50 & -0.47 & -0.47 \\
\hline M0002A-3X & 5.00 & 5.26 & 105 & 6.50 & 4.54 & 4.54 \\
\hline M0002A-4X & 5.00 & 5.29 & 106 & 11.50 & 0.00 & 0.00 \\
\hline M0002A-5X & 5.00 & 2.46 & 49 & 16.50 & 3.84 & 3.92 \\
\hline
\end{tabular}


Table T1 (continued).

\begin{tabular}{|c|c|c|c|c|c|c|}
\hline Core & $\begin{array}{l}\text { Length } \\
\text { cored } \\
\text { (m) }\end{array}$ & $\begin{array}{l}\text { Length } \\
\text { recovered } \\
(\mathrm{m})\end{array}$ & $\begin{array}{l}\text { Recovery } \\
(\%)\end{array}$ & $\begin{array}{c}\text { Top of core } \\
\text { (mbsf) }\end{array}$ & $\begin{array}{l}\text { Offsets for } \\
\text { mcd scale } \\
\text { (m) }\end{array}$ & $\begin{array}{l}\text { Offsets for } \\
\text { rmcd scale } \\
\text { (m) }\end{array}$ \\
\hline M0002A-6X & 5.00 & 5.20 & 104 & 21.50 & 1.66 & 2.42 \\
\hline M0002A-7X & 5.00 & 4.08 & 82 & 26.50 & 4.57 & 2.62 \\
\hline M0002A-8X & 4.50 & 3.53 & 78 & 31.00 & 4.57 & 2.42 \\
\hline M0002A-9X & 5.00 & 4.35 & 87 & 36.00 & 4.01 & 1.06 \\
\hline M0002A-10X & 5.00 & 3.80 & 76 & 41.00 & 3.51 & 0.56 \\
\hline M0002A-11X & 4.00 & 4.44 & 111 & 46.00 & 2.39 & 0.00 \\
\hline $\mathrm{M} 0002 \mathrm{~A}-12 \mathrm{X}$ & 5.00 & 3.29 & 66 & 50.00 & 2.94 & 0.00 \\
\hline M0002A-13X & 5.00 & 1.41 & 28 & 55.00 & 2.94 & 0.00 \\
\hline M0002A-14X & 4.00 & 3.39 & 85 & 60.00 & 0.00 & 0.00 \\
\hline M0002A-15X & 5.00 & 4.20 & 84 & 64.00 & 0.00 & 0.00 \\
\hline M0002A-16X & 5.00 & 3.53 & 71 & 69.00 & 0.34 & 0.34 \\
\hline M0002A-17X & 5.00 & 2.10 & 42 & 74.00 & 0.00 & 0.00 \\
\hline M0002A-18X & 3.20 & 2.15 & 67 & 79.00 & 0.00 & 0.00 \\
\hline M0002A-19X & 5.00 & 1.06 & 21 & 81.20 & 0.00 & 0.00 \\
\hline M0002A-20X & 5.00 & 4.95 & 99 & 86.20 & 0.00 & 0.00 \\
\hline$M 0002 A-21 X$ & 5.00 & 3.50 & 70 & 91.20 & 0.00 & 0.00 \\
\hline $\mathrm{M} 0002 \mathrm{~A}-22 \mathrm{X}$ & 5.00 & 0.39 & 8 & 96.20 & 0.00 & 0.00 \\
\hline M0002A-23X & 5.00 & 1.33 & 27 & 101.20 & 0.00 & 0.00 \\
\hline M0002A-24X & 4.00 & 4.71 & 118 & 106.20 & 0.00 & 0.00 \\
\hline $\mathrm{M} 0002 \mathrm{~A}-25 \mathrm{X}$ & 5.00 & 3.92 & 78 & 110.20 & 0.50 & 0.50 \\
\hline M0002A-26X & 5.00 & 2.14 & 43 & 115.20 & 0.00 & 0.00 \\
\hline M0002A-27X & 5.00 & 3.60 & 72 & 120.20 & 0.00 & 0.00 \\
\hline M0002A-28X & 3.00 & 2.34 & 78 & 125.20 & 0.00 & 0.00 \\
\hline M0002A-29X & 5.00 & 3.97 & 79 & 128.20 & 0.00 & 0.00 \\
\hline M0002A-30X & 1.50 & 2.79 & 186 & 133.20 & 0.00 & 0.00 \\
\hline M0002A-31X & 5.00 & 1.50 & 30 & 134.70 & 3.00 & 3.00 \\
\hline M0002A-32X & 4.50 & 5.32 & 118 & 139.70 & 0.00 & 0.00 \\
\hline M0002A-33X & 4.80 & 3.87 & 81 & 144.20 & 0.80 & 0.80 \\
\hline $\mathrm{M} 0002 \mathrm{~A}-34 \mathrm{X}$ & 5.00 & 3.05 & 61 & 149.00 & 0.00 & 0.00 \\
\hline $\mathrm{M} 0002 \mathrm{~A}-35 \mathrm{X}$ & 5.00 & 5.48 & 110 & 154.00 & 0.00 & 0.00 \\
\hline M0002A-36X & 3.00 & 0.21 & 7 & 159.00 & 0.00 & 0.00 \\
\hline M0002A-37X & 3.00 & 3.42 & 114 & 164.00 & -1.00 & -1.00 \\
\hline M0002A-38X & 4.18 & 5.31 & 127 & 167.00 & 0.00 & 0.00 \\
\hline M0002A-39X & 2.40 & 1.03 & 43 & 171.18 & 1.20 & 1.20 \\
\hline M0002A-40X & 5.00 & 5.28 & 106 & 173.58 & 0.00 & 0.00 \\
\hline M0002A-41X & 4.41 & 0.17 & 4 & 178.58 & 0.00 & 0.00 \\
\hline $\mathrm{M} 0002 \mathrm{~A}-42 \mathrm{X}$ & 5.00 & 4.92 & 98 & 182.49 & 0.00 & 0.00 \\
\hline M0002A-43X & 4.50 & 4.53 & 101 & 187.49 & 0.00 & 0.00 \\
\hline $\mathrm{M} 0002 \mathrm{~A}-44 \mathrm{X}$ & 5.00 & 3.94 & 79 & 191.99 & 0.00 & 0.00 \\
\hline M0002A-45X & 0.01 & 1.49 & $\begin{array}{l}\text { No advance } \\
\text { but recovery }\end{array}$ & 195.99 & 0.00 & 0.00 \\
\hline $\mathrm{M} 0002 \mathrm{~A}-46 \mathrm{X}$ & 5.00 & 3.63 & 73 & 197.00 & 0.57 & 0.57 \\
\hline M0002A-47X & 3.50 & 5.49 & 157 & 202.00 & -0.56 & -0.56 \\
\hline $\mathrm{M} 0002 \mathrm{~A}-48 \mathrm{X}$ & 4.50 & 5.20 & 116 & 205.50 & 1.14 & 1.14 \\
\hline M0002A-49X & 5.00 & 5.50 & 110 & 210.00 & 2.32 & 2.32 \\
\hline M0002A-50X & 3.74 & 2.24 & 60 & 215.00 & 2.88 & 2.88 \\
\hline M0002A-51X & 2.20 & 2.68 & 122 & 218.74 & 3.32 & 3.32 \\
\hline M0002A-52X & 4.00 & 1.95 & 49 & 220.94 & 4.02 & 4.02 \\
\hline M0002A-53X & 5.00 & 5.29 & 106 & 225.00 & 1.82 & 1.82 \\
\hline M0002A-54X & 5.00 & 0.51 & 10 & 230.00 & 2.02 & 2.02 \\
\hline M0002A-55X & 4.60 & 5.40 & 117 & 235.00 & 1.07 & 1.07 \\
\hline M0002A-56X & 5.00 & 3.64 & 73 & 239.60 & 1.82 & 1.82 \\
\hline M0002A-57X & 5.00 & 5.57 & 111 & 244.60 & 1.82 & 1.82 \\
\hline M0002A-58X & 5.00 & 5.22 & 104 & 249.60 & 1.82 & 1.82 \\
\hline M0002A-59X & 5.00 & 4.47 & 89 & 254.60 & 1.82 & 1.82 \\
\hline M0002A-60X & 5.00 & 4.55 & 91 & 257.60 & 2.94 & 2.94 \\
\hline M0002A-61X & 5.00 & 2.58 & 52 & 262.60 & 1.88 & 1.88 \\
\hline M0002A-62X & 2.50 & 4.09 & 164 & 276.60 & 1.82 & 1.82 \\
\hline
\end{tabular}

Notes: Top of core data from drillers log. Offsets for mcd scale from Backman et al. (2008). 
Table T2. Revised splice tie table. (Continued on next page.)

\begin{tabular}{|c|c|c|c|c|c|c|}
\hline \multirow{2}{*}{$\begin{array}{l}\text { Core, section, } \\
\text { interval }(\mathrm{cm})\end{array}$} & \multicolumn{2}{|c|}{ Depth } & & \multirow{2}{*}{$\begin{array}{l}\text { Core, section, } \\
\text { interval }(\mathrm{cm})\end{array}$} & \multicolumn{2}{|c|}{ Depth } \\
\hline & mbsf & rmcd & & & mbsf & rmcd \\
\hline $302-$ & & & & $302-$ & & \\
\hline M0004C-1H-3, 65.7 & 3.68 & 3.68 & Tie to & M0004C-2H-1, 34 & 4.34 & 3.68 \\
\hline $\mathrm{M} 0004 \mathrm{C}-2 \mathrm{H}-3,123$ & 8.24 & 7.58 & Tie to & M0003A-1H-3, 84 & 3.85 & 7.58 \\
\hline M0003A-1H-3, 138.4 & 4.40 & 8.13 & Tie to & M0004C-3H-1, 26 & 9.21 & 8.13 \\
\hline M0004C-3H-3, 150 & 13.47 & 12.39 & Tie to & M0003A-2H-2, 82 & 7.32 & 12.39 \\
\hline $\mathrm{M} 0003 \mathrm{~A}-2 \mathrm{H}-4,5$ & 9.37 & 14.44 & Tie to & M0004C- $4 \mathrm{H}-2,35$ & 15.82 & 14.44 \\
\hline M0004C-4H-3, 46 & 17.43 & 16.05 & Tie to & M0003A-3H-2, 19 & 11.69 & 16.05 \\
\hline M0003A-3H-4, 33 & 14.70 & 19.06 & Tie to & M0004A-1H-1, 148 & 18.48 & 19.06 \\
\hline M0004A-1H-4, 11 & 20.34 & 20.92 & Tie to & M0004A-2X-1, 61 & 21.11 & 20.92 \\
\hline M0004A-2X-3, 76 & 24.26 & 24.07 & Tie to & M0004A-3X-1, 16 & 25.66 & 24.07 \\
\hline M0004A-3X-2, 128 & 28.28 & 26.69 & Tie to & M0002A-6X-2, 142 & 24.27 & 26.69 \\
\hline M0002A-6X-4, 65 & 26.52 & 28.94 & Append to & M0002A-7X-1, 0 & 26.50 & 29.12 \\
\hline M0002A-7X-4, 65 & 30.40 & 33.02 & Append to & M0002A-9X-1, 0 & 36.00 & 37.06 \\
\hline M0002A-9X-5, 44 & 41.43 & 42.49 & Append to & M0002A-10X-1, 0 & 41.00 & 41.56 \\
\hline M0002A-10X-3, 73 & 44.73 & 45.29 & Append to & M0002A-11X-1, 0 & 46.00 & 46.00 \\
\hline M0002A-11X-3, 141 & 50.41 & 50.41 & Append to & M0002A-12X-1, 0 & 50.02 & 50.02 \\
\hline M0002A-12X-3, 67 & 53.19 & 53.19 & Append to & M0002A-13X-1, 0 & 55.00 & 55.00 \\
\hline M0002A-13X-1, 144 & 56.44 & 56.44 & Append to & M0002A-14X-1, 0 & 60.00 & 60.00 \\
\hline M0002A-14X-3, 75 & 63.26 & 63.26 & Append to & M0002A-15X-1, 0 & 65.00 & 65.00 \\
\hline M0002A-15X-3, 121 & 69.22 & 69.22 & Append to & M0002A-16X-1, 0 & 69.00 & 69.34 \\
\hline M0002A-16X-CC, 8 & 72.42 & 72.76 & Append to & M0002A-17X-1, 0 & 74.00 & 74.00 \\
\hline M0002A-17X-CC, 13 & 76.03 & 76.03 & Append to & M0002A-18X-1, 0 & 78.00 & 78.00 \\
\hline M0002A-18X-CC, 8 & 80.08 & 80.08 & Append to & M0002A-19X-1, 0 & 81.20 & 81.20 \\
\hline M0002A-19X-1, 103 & 82.23 & 82.23 & Append to & M0002A-20X-1, 0 & 86.20 & 86.20 \\
\hline M0002A-20X-4, 13 & 90.85 & 90.85 & Append to & M0002A-21X-1, 0 & 91.20 & 91.20 \\
\hline M0002A-21X-3, 33 & 94.55 & 94.55 & Append to & M0002A-22X-1, 0 & 96.20 & 96.20 \\
\hline M0002A-22X-1, 38 & 96.58 & 96.58 & Append to & M0002A-23X-1, 0 & 99.83 & 99.83 \\
\hline M0002A-23X-2, 108 & 102.41 & 102.41 & Append to & M0002A-24X-1, 0 & 106.20 & 106.20 \\
\hline M0002A-24X-3, 143 & 110.63 & 110.63 & Append to & M0002A-25X-1, 0 & 110.20 & 110.70 \\
\hline M0002A-25X-3, 85 & 114.08 & 114.58 & Append to & M0002A-26X-1, 0 & 115.20 & 115.20 \\
\hline $\mathrm{M} 0002 \mathrm{~A}-26 \mathrm{X}-2,63$ & 117.33 & 117.33 & Append to & M0002A-27X-1, 0 & 120.50 & 120.50 \\
\hline M0002A-27X-3, 42 & 123.93 & 123.93 & Append to & M0002A-28X-1, 0 & 125.20 & 125.20 \\
\hline M0002A-28X-2, 68 & 127.38 & 127.38 & Append to & M0002A-29X-1, 0 & 128.20 & 128.20 \\
\hline M0002A-29X-3, 78 & 131.98 & 131.98 & Append to & M0002A-30X-1, 0 & 133.20 & 133.20 \\
\hline M0002A-30X-3, 73 & 136.94 & 136.94 & Append to & M0002A-31X-1, 0 & 134.70 & 137.70 \\
\hline M0002A-31X-3, 11 & 136.16 & 139.16 & Append to & M0002A-32X-1, 0 & 139.70 & 139.70 \\
\hline M0002A-32X-4, 63 & 144.85 & 144.85 & Append to & M0002A-33X-1, 0 & 144.20 & 145.00 \\
\hline M0002A-33X-CC, 13 & 148.00 & 148.80 & Append to & M0002A-34X-1, 0 & 149.00 & 149.00 \\
\hline M0002A-34X-CC, 8 & 151.95 & 151.95 & Append to & M0002A-35X-1, 0 & 152.77 & 152.77 \\
\hline $\mathrm{M} 0002 \mathrm{~A}-35 \mathrm{X}-5,63$ & 159.42 & 159.42 & Append to & M0002A-37X-1, 0 & 163.50 & 162.50 \\
\hline M0002A-37X-3, 38 & 166.90 & 165.90 & Tie to & M0002A-38X-1, 0 & 166.50 & 166.50 \\
\hline M0002A-38X-5, 54 & 171.66 & 171.66 & Append to & M0002A-39X-1, 0 & 170.68 & 171.88 \\
\hline M0002A-39X-CC, 17 & 171.65 & 172.85 & Append to & M0002A-40X-1, 0 & 173.08 & 173.08 \\
\hline $\mathrm{M} 0002 \mathrm{~A}-40 \mathrm{X}-\mathrm{CC}, 10$ & 178.34 & 178.34 & Append to & M0002A-41X-1, 0 & 178.58 & 178.58 \\
\hline M0002A-41X-1, 13 & 178.71 & 178.71 & Append to & M0002A-42X-1, 0 & 182.49 & 182.49 \\
\hline M0002A-42X-CC, 8 & 187.33 & 187.33 & Append to & $02 \mathrm{~A}-43 \mathrm{X}-1,0$ & 187.49 & 187.49 \\
\hline M0002A-43X-3, 151 & 192.00 & 192.00 & Append to & M0002A-44X-1, 0 & 191.99 & 191.99 \\
\hline M0002A-44X-4, 13 & 195.86 & 195.86 & Append to & M0002A-45X-1, 0 & 195.93 & 195.93 \\
\hline $\mathrm{M} 0002 \mathrm{~A}-45 \mathrm{X}-2,13$ & 197.40 & 197.40 & Append to & M0002A-46X-1, 0 & 197.00 & 197.57 \\
\hline M0002A-46X-3, 53 & 200.53 & 201.10 & Append to & M0002A-47X-1, 0 & 202.00 & 201.44 \\
\hline M0002A-47X-CC, 13 & 207.43 & 206.87 & Tie to & M0002A-48X-1, 0 & 205.50 & 206.64 \\
\hline M0002A-48X-CC, 8 & 210.66 & 211.80 & Append to & M0002A-49X-1, 0 & 210.00 & 212.32 \\
\hline M0002A-49X-CC, 13 & 215.47 & 217.79 & Append to & M0002A-50X-1, 0 & 215.00 & 217.88 \\
\hline M0002A-50X-2, 63 & 217.14 & 220.02 & Append to & M0002A-51X-1, 0 & 218.74 & 222.06 \\
\hline M0002A-51X-2, 113 & 221.38 & 224.70 & Append to & M0002A-52X-1, 0 & 220.94 & 224.96 \\
\hline M0002A-52X-CC, 6 & 222.87 & 226.89 & Append to & M0002A-53X-1, 7 & 225.07 & 226.89 \\
\hline M0002A-53X-CC, 8 & 230.22 & 232.04 & Append to & M0002A-54X-1, 0 & 230.00 & 232.02 \\
\hline M0002A-54X-1, 38 & 230.38 & 232.40 & Append to & M0002A-55X-1, 0 & 235.00 & 236.07 \\
\hline M0002A-55X-5, 66 & 240.29 & 241.36 & Append to & M0002A-56X-1, 0 & 239.60 & 241.42 \\
\hline M0002A-56X-CC, 18 & 243.12 & 244.94 & Append to & M0002A-57X-1, 0 & 244.60 & 246.42 \\
\hline M0002A-57X-5, 61 & 249.90 & 251.72 & Append to & M0002A-58X-1, 27 & 249.90 & 251.72 \\
\hline M0002A-58X-4, 53 & 254.66 & 256.48 & Append to & M0002A-59X-1, 0 & 254.60 & 256.42 \\
\hline M0002A-59X-3, 129 & 258.92 & 260.74 & Append to & M0002A-60X-1, 19 & 257.80 & 260.74 \\
\hline M0002A-60X-3, 98 & 261.60 & 264.54 & Append to & M0002A-61X-1, 0 & 262.60 & 264.48 \\
\hline M0002A-61X-CC, 13 & 265.42 & 267.30 & Tie to & M0002A-62X-1, 0 & 267.60 & 269.42 \\
\hline M0002A-62X-3, 98 & 271.59 & 273.41 & Append to & M0004A-6X-1, 0 & 273.50 & 273.50 \\
\hline M0004A-6X-5, 10 & 278.70 & 278.70 & Append to & M0004A-7X-1, 0 & 278.50 & 278.70 \\
\hline M0004A-7X-4, 83 & 283.68 & 283.88 & Append to & M0004A-8X-1, 0 & 282.30 & 286.30 \\
\hline
\end{tabular}


Table T2 (continued).

\begin{tabular}{|c|c|c|c|c|c|c|}
\hline \multirow{2}{*}{$\begin{array}{l}\text { Core, section, } \\
\text { interval }(\mathrm{cm})\end{array}$} & \multicolumn{2}{|c|}{ Depth } & & \multirow{2}{*}{$\begin{array}{l}\text { Core, section, } \\
\text { interval }(\mathrm{cm})\end{array}$} & \multicolumn{2}{|c|}{ Depth } \\
\hline & mbsf & rmcd & & & mbsf & rmcd \\
\hline M0004A-8X-1, 20 & 282.50 & 286.50 & Append to & M0004A-9X-1, 0 & 287.30 & 287.30 \\
\hline M0004A-9X-1, 26 & 287.56 & 287.56 & Append to & M0004A-10X-1, 0 & 291.85 & 291.85 \\
\hline M0004A-10X-4, 67 & 297.00 & 297.00 & Append to & M0004A-11X-1, 0 & 297.30 & 297.30 \\
\hline M0004A-11X-4, 84 & 302.67 & 302.67 & Append to & M0004A-15X-1, 0 & 313.35 & 313.35 \\
\hline M0004A-15X-1, 26 & 313.61 & 313.61 & Append to & M0004A-19X-1, 0 & 320.53 & 320.53 \\
\hline M0004A-19X-2, 151 & 323.53 & 323.53 & Append to & M0004A-20X-1, 0 & 326.28 & 326.28 \\
\hline M0004A-20X-CC, 17 & 328.24 & 328.24 & Append to & M0004A-21X-1, 0 & 329.28 & 329.28 \\
\hline M0004A-21X-4, 15 & 332.84 & 332.84 & Append to & M0004A-22X-1, 0 & 339.00 & 339.00 \\
\hline M0004A-22X-1, 96 & 339.96 & 339.96 & Tie to & M0004A-23X-1, 0 & 341.60 & 341.60 \\
\hline M0004A-23X-CC, 16 & 345.61 & 345.61 & Tie to & M0004A-27X-1, 0 & 367.40 & 367.40 \\
\hline M0004A-27X-4, 29 & 372.24 & 372.24 & Append to & M0004A-28X-1, 0 & 371.80 & 372.27 \\
\hline M0004A-28X-4, 65 & 377.04 & 377.51 & Append to & M0004A-29X-1, 0 & 375.80 & 377.80 \\
\hline M0004A-29X-1, 132 & 377.12 & 379.12 & Append to & M0004A-30X-1, 0 & 380.30 & 380.30 \\
\hline M0004A-30X-3, 120 & 384.53 & 384.53 & Append to & M0004A-31X-1, 0 & 383.20 & 384.70 \\
\hline M0004A-31X-CC, 43 & 383.63 & 385.13 & Append to & M0004A-32X-1, 0 & 388.00 & 388.00 \\
\hline M0004A-32X-3, 14 & 391.02 & 391.02 & Append to & M0004A-33X-1, 0 & 392.50 & 392.50 \\
\hline M0004A-33X-CC, 8 & 394.08 & 394.08 & Append to & M0004A-34X-1, 0 & 396.25 & 396.25 \\
\hline M0004A-34X-3, 101 & 400.03 & 400.03 & Append to & M0004A-35X-1, 0 & 401.20 & 401.20 \\
\hline M0004A-35X-4, 13 & 404.76 & 404.76 & Append to & M0004A-41X-1, 0 & 424.50 & 424.50 \\
\hline M0004A-41X-1, 26 & 424.76 & 424.76 & Append to & M0004A-42X-1, 0 & 426.60 & 426.60 \\
\hline M0004A-42X-1, 72 & 427.32 & 427.32 & & & & \\
\hline
\end{tabular}


Table T3. Tie points required to "stretch" and "squeeze" material in Holes M0003A, M0004C, and M0004A to best fit the revised composite splice record. (See table note.)

\begin{tabular}{|c|c|c|c|}
\hline \multirow{2}{*}{$\begin{array}{l}\text { Core, section, } \\
\text { interval }(\mathrm{cm})\end{array}$} & \multicolumn{2}{|c|}{ Depth } & \multirow{2}{*}{$\begin{array}{l}\text { Difference } \\
\quad(\mathrm{m})\end{array}$} \\
\hline & mbsf & rmcd & \\
\hline \multicolumn{4}{|l|}{$302-$} \\
\hline M0004A-1H-1, 0 & 17.00 & 17.60 & 0.60 \\
\hline M0004A-1H-1, 148 & 18.48 & 19.06 & 0.58 \\
\hline M0004A-1H-4, 11 & 20.34 & 20.92 & 0.58 \\
\hline M0004A-1H-4, 27.20 & 20.52 & 21.09 & 0.57 \\
\hline M0004A-2X-1, 0 & 20.50 & 20.28 & -0.22 \\
\hline M0004A-2X-1, 61 & 21.11 & 20.92 & -0.19 \\
\hline M0004A-2X-3, 73 & 24.23 & 24.04 & -0.19 \\
\hline M0004A-2X-3, 76 & 24.26 & 24.07 & -0.19 \\
\hline M0004A-3X-1, 0 & 25.50 & 23.91 & -1.59 \\
\hline M0004A-3X-1, 13 & 25.63 & 24.04 & -1.59 \\
\hline M0004A-3X-2, 126 & 28.26 & 26.67 & -1.59 \\
\hline M0004C-1H-1, 0 & 0.00 & 0.00 & 0.00 \\
\hline M0004C-1H-4, 13.60 & 3.86 & 3.86 & 0.00 \\
\hline M0004C-2H-1, 0 & 4.00 & 3.34 & -0.66 \\
\hline M0004C-2H-1, 130 & 5.30 & 4.64 & -0.66 \\
\hline M0004C-2H-5, 17.90 & 8.92 & 8.27 & -0.65 \\
\hline M0004C-3H-1, 0 & 8.95 & 7.81 & -1.14 \\
\hline M0004C-3H-1, 26 & 9.21 & 8.13 & -1.08 \\
\hline M0004C-3H-4, 0 & 13.47 & 12.39 & -1.08 \\
\hline M0004C-3H-5, 24.80 & 13.93 & 12.85 & -1.08 \\
\hline M0004C-4H-1, 0 & 13.97 & 12.59 & -1.38 \\
\hline M0004C-4H-1, 94 & 14.91 & 13.57 & -1.34 \\
\hline M0004C-4H-2, 35 & 15.82 & 14.44 & -1.38 \\
\hline M0004C-4H-3, 43.20 & 17.43 & 16.05 & -1.38 \\
\hline M0004C-4H-3, 1.30 & 18.25 & 16.83 & -1.42 \\
\hline M0004C-4H-4, 19.80 & 18.55 & 17.04 & -1.51 \\
\hline M0004C-5X-1, 0 & 18.57 & 17.20 & -1.37 \\
\hline M0004C-5X-1, 22 & 18.79 & 17.43 & -1.36 \\
\hline M0004C-5X-1, 42 & 18.99 & 17.60 & -1.39 \\
\hline M0004C-5X-1, 72 & 19.29 & 18.05 & -1.24 \\
\hline M0003A-1H-1, 0 & 0.00 & 3.19 & 3.19 \\
\hline M0003A-1H-1, 0.20 & 0.23 & 3.42 & 3.19 \\
\hline M0003A-1H-1, 0.80 & 0.79 & 4.00 & 3.21 \\
\hline M0003A-1H-1, 112 & 1.12 & 4.66 & 3.54 \\
\hline M0003A-1H-2, 0 & 1.53 & 5.17 & 3.64 \\
\hline M0003A-1H-2, 0.30 & 1.83 & 5.44 & 3.61 \\
\hline M0003A-1H-2, 0.60 & 2.09 & 5.76 & 3.67 \\
\hline M0003A-1H-2, 99.4 & 2.50 & 6.20 & 3.70 \\
\hline M0003A-1H-3, 0.80 & 3.85 & 7.58 & 3.73 \\
\hline M0003A-1H-3, 1.40 & 4.40 & 8.13 & 3.73 \\
\hline M0003A-1H-5, 21.1 & 5.00 & 8.73 & 3.73 \\
\hline M0003A-2H-1, 0 & 5.00 & 9.89 & 4.89 \\
\hline M0003A-2H-1, 0.50 & 5.46 & 10.31 & 4.85 \\
\hline M0003A-2H-1, 0.90 & 5.93 & 10.86 & 4.93 \\
\hline M0003A-2H-1, 1.20 & 6.20 & 11.17 & 4.97 \\
\hline M0003A-2H-1, 1.40 & 6.41 & 11.52 & 5.11 \\
\hline M0003A-2H-2, 0.40 & 6.88 & 11.82 & 4.94 \\
\hline M0003A-2H-2, 0.70 & 7.18 & 12.27 & 5.09 \\
\hline M0003A-2H-2, 81.60 & 7.32 & 12.39 & 5.07 \\
\hline M0003A-2H-4, 0.10 & 9.37 & 14.44 & 5.07 \\
\hline M0003A-2H-4, 25.30 & 9.58 & 14.65 & 5.07 \\
\hline M0003A-3H-1, 0 & 10.01 & 14.17 & 4.16 \\
\hline M0003A-3H-1, 0.20 & 10.22 & 14.54 & 4.32 \\
\hline M0003A-3H-1, 0.30 & 10.33 & 14.65 & 4.32 \\
\hline M0003A-3H-1, 0.70 & 10.74 & 15.12 & 4.38 \\
\hline M0003A-3H-1, 1.20 & 11.20 & 15.56 & 4.36 \\
\hline M0003A-3H-2, 0.20 & 11.69 & 16.05 & 4.36 \\
\hline M0003A-3H-4, 0.30 & 14.70 & 19.06 & 4.36 \\
\hline M0003A-3H-4, 58 & 14.96 & 19.32 & 4.36 \\
\hline
\end{tabular}

Note: These ties are only needed when analyzing material that lies outside the splice trail. 
Table T4. Tie points used to stratigraphically correlate ACEX composite depth scale with Cores 96/12-1PC and PS-2185-6. (See table note.)

\begin{tabular}{rcc}
\hline \multicolumn{3}{c}{ Depth } \\
\hline $\begin{array}{c}\text { ACEX } \\
\text { (rmcd) }\end{array}$ & $\begin{array}{c}\text { Core } \\
\text { PS-2185-6 } \\
(\mathrm{m})\end{array}$ & $\begin{array}{c}\text { Core } \\
96 / 12-\text { PC } \\
(\mathrm{m})\end{array}$ \\
\hline 0.08 & 0.06 & 0.01 \\
0.43 & 0.26 & 0.30 \\
1.57 & 1.18 & 1.63 \\
2.42 & 1.70 & 1.93 \\
2.82 & 2.05 & 2.05 \\
3.23 & 2.31 & 2.19 \\
4.63 & 3.07 & 2.57 \\
5.57 & 3.68 & 2.86 \\
6.49 & 4.35 & 3.14 \\
7.19 & 4.93 & 3.53 \\
7.82 & 5.41 & 3.85 \\
7.90 & 5.54 & 3.90 \\
8.15 & 5.70 & 4.06 \\
8.76 & 6.18 & 4.41 \\
9.18 & 6.52 & 4.65 \\
9.26 & 6.65 & 4.84 \\
9.70 & 7.00 & 5.21 \\
10.29 & 7.45 & 5.52 \\
11.02 & & 6.05 \\
11.60 & & 6.64 \\
12.24 & & 7.11 \\
\hline
\end{tabular}

Note: Ties presented here represent the minimum number of ties required to correlate bulk density records from these cores. 